\title{
THE ASSUMPTION OF RISK DEFENSE AND THE SEXUAL TRANSMISSION OF AIDS: A PROPOSAL FOR THE APPLICATION OF COMPARATIVE KNOWLEDGE
}

\author{
KATHERINE A. KELLY†
}

\section{INTRODUCTION}

Aristotle maintained that "[p]leasures impede wise thinking,... for while [they] last no one can think of anything. ${ }^{n 1}$ Although the absolute nature of Aristotle's statement is questionable, the premise behind it may help to explain the continued, rapid spread of Human Immunodeficiency Virus (HIV), the causative agent of Acquired Immune Deficiency Syndrome (AIDS), in an era of informed decision-making. ${ }^{2}$ It is common knowledge that AIDS is a deadly, incurable disease transferred through sexual contact, yet individuals continue to engage in sexual activity with persons of unknown HIV status; ${ }^{3}$ it is common knowledge that the spread of HIV can be greatly reduced through the use of condoms, ${ }^{4}$ yet

† B.S. 1990, State University of New York at Binghamton; M.S. 1992, Syracuse University;J.D. Candidate 1996, University of Pennsylvania. Many thanks to Professor Michael S. Moore for his inspiration and to Daniel G. Rice, Andrew R. Schiesl, Hilary A. Siegel, Pragati K. Balsawer, Suann C. MacIsaac, Daniel D. Dex, my family, and the members the Law Review for their assistance and support.

${ }^{1}$ ARISTOTLE, THE Nicomachean ETHICs 1152b, lns. 16-18 (Hippocrates G. Apostle trans., 1975); see also ROLLO MAY, LOVE AND WILL 38 (1969) (stating that sex "remains the power of procreation, the drive which perpetuates the race, the source at once of the human being's most intense pleasure and his most pervasive anxiety[;] [i]t can, in its daimonic form, hurl the individual into sloughs of despond, and, when allied with eros, it can lift him out of his despondency into orbits of ecstasy").

2 In 1993, AIDS became the leading cause of death for persons aged 25 to 44 years old. See Update: Acquired Immunodeficiency Syndrome-United States, 1994, 44 MORBIDITY \& MORTALITY WKLY. REP. 64, 67 (1995) [hereinafter AIDS Update]; see also Update: Mortality Attributable to HIV Infection/AIDS Among Persons Aged 25-44 YearsUnited States, 1990 and 1991, 42 MORBIDITY \& MORTALITY WKLY. REP. 481, 483 (1993) [hereinafter Mortality Update] (providing figures indicating that from 1982 to 1991 deaths caused by "HIV infection" increased in an approximately exponential fashion).

${ }^{3}$ Cf. Helena Brett-Smith \& Gerald H. Friedland, Transmission and Treatment, in AIDS LAW TODAY 18, 20 (Scott Burris et al. eds., 1993) (stating that "in the United States large numbers of currently uninfected people remain at risk because of their ongoing patterns of behavior").

"The term "condom" as used in this Comment is intended to mean "latex condom." See tomas J. Philipson \& Richard A. Posner, Private Choices and Public Health: The AIDS EPIDEmic IN AN ECONOMIC Perspective 23-24 (1993) (noting that the latex condom reduces the risk of HIV transmission). Some condoms 
individuals partake in unprotected sexual activity. AIDS is the most feared and dreaded disease in our society, ${ }^{5}$ yet individuals will not sacrifice pleasure to escape its wrath. ${ }^{6}$

Because educating individuals on the effects of AIDS has not proved sufficient to deter completely the spread of the disease, society must attempt to devise additional means of curtailing the pandemic. The legal system can help meet this challenge by creating deterrents to the spread of HIV. Effective legal deterrents are valuable not only to protect potential victims, but also to lessen the profound impact of the AIDS epidemic "on the legal, social, economic, and ethical institutions and structures of our society."

To deter the spread of HIV, the legal system must discourage activities that contribute to disease transmission. Most importantly, the law must dissuade individuals from engaging in "unprotected anal sex; unprotected vaginal sex; unprotected oral/genital and oral/anal sex; unprotected sex with many partners; [and from] having sex while drunk or high." how the law can most effectively allocate the burdens associated with the negligent sexual transmission of HIV. Drawing upon fundamental concepts of tort and contract law, this Comment seeks to balance the negligence cause of action and the assumption of risk defense in a manner that achieves an optimal degree of deterrence to HIV-transmitting sexual conduct.

To maximize tort law's deterrent effect, this Comment proposes a new formulation of the assumption of risk defense that correlates legal burdens with parties' relative degrees of knowledge of

are made of lamb intestine, but it is unclear whether such condoms are effective against the spread of HIV. See id. at 23 n.27; see also PETER GOULD, THE SLOW Plague: A GEOGRAPHY OF THE AIDS PANDEMIC 48 (1993) (noting that some condoms are made of animal skins "even though the animal membranes are not barriers to the passage of $\mathrm{HIV}^{n}$ ).

${ }^{5}$ See Prevention and Control of Acquired Immunodeficiency Syndrome: An Interim Report, 258 JAMA 2097, 2097 (1987) (referring to a Gallup poll indicating that AIDS is the highest health priority for many individuals); Fear of AIDS Rivals Worry Over Cancer, N.Y. TIMEs, May 12, 1987, at C3 (stating that a Media General-Associated Press poll reported that $48 \%$ of individuals who feared one disease over all others feared AIDS the most).

${ }^{6}$ Cf. AIDS Update, supra note 2, at $64-65$ (noting that over 43,000 of the 80,691 AIDS cases reported in 1994 involved individuals whose only exposure to the virus was through sexual contact).

7 AIDS COORDINATING COMM., AMERICAN BAR ASS'N, AIDS: THE LEGAL IsSUES 13 (Discussion Draft 1988) [hereinafter ABA REPORT].

${ }^{8}$ Doe v. Johnson, 817 F. Supp. 1382, 1390-91 (W.D. Mich) (citation omitted), cause dismissed sub nom. Moore v. Johnson, 826 F. Supp. 1106 (W.D. Mich. 1993). 
potential HIV-transmission risks. This comparative knowledge approach to apportioning legal responsibilities deters both infected and uninfected individuals ${ }^{9}$ from risky conduct by placing the cost of the HIV transmission on the party better situated to know of the risk involved in the sexual encounter. The approach serves the deterrent goals of tort law more effectively than the current assumption of risk defense, retains a firm grounding in common-law policies and principles, and resolves many of the tensions and inconsistencies that pervade current tort law. The benefits of the proposal suggest the utility of the comparative knowledge formulation not only for curbing the spread of HIV, but also for apportioning risks in numerous other contexts where the assumption of risk doctrine has proven inadequate.

Part I of this Comment provides a brief description of the pathology of AIDS. Part II demonstrates the ability of the tort law to deter the spread of HIV and examines how present principles of the negligence cause of action and the assumption of risk defense apply to the tort of negligent sexual transmission of HIV. Part III presents the deficiencies of current assumption of risk doctrine. Finally, Part IV proposes a comparative knowledge analysis as a reformulation of present assumption of risk doctrine.

\section{ACQUIRED IMMUNE DEFICIENCY SYNDROME: AN OVERVIEW OF THE DISEASE}

AIDS, an incurable disease first identified in $1983,{ }^{10}$ is the last phase of infection by HIV. ${ }^{11}$ HIV, also referred to as Human T-

${ }^{9}$ Cf. John H. Mansfield, Informed Choice in the Law of Torts, 22 LA. L. REv. 17, 53 (1961) (stating that " $[w]$ hen the plaintiff is denied recovery . . . it must be that our desire to deter the defendant and our willingness to make him compensate for any injuries that have occurred are outweighed by a desire to deter the plaintiff and educate [her] to a responsible exercise of [her] power of choice").

${ }^{10}$ See TASK FORCE ON ACQUIREd IMMUNE DEFICIENCY SYNDROME, PENNSYlvania BAR ASS'N, AIDS: LAW AND SOCIETY 5 (1989) [hereinafter TASK FORCE REPORT]; see also June E. Osborn, The AIDS Epidemic: Discovery of a New Disease, in AIDS AND THE LAw: A GuIDE FOR THE PUBLIC 17, 19 (Harlon L. Dalton et al. eds., 1987) (noting that "the first sufferers of what we now call AIDS were described in the summer of 1981"); cf. GoULD, supra note 4, at 109, 201 (noting that HIV-1 was first identified in 1982).

Although it took until 1983 to isolate the virus, there is evidence that the virus first appeared in Africa in the 1950s, and in the United States in 1978. See id. at 12 (noting that blood samples which were extracted from a Danish surgeon in Zaire in 1959 were later found to contain HIV); Osborn, supra, at 23 (stating that ${ }^{\prime}[\mathrm{r}]$ etrospective testing of stored serum samples has confirmed that the virus first appeared in the United States in 1978").

"See U.S. Pub. Health Serv., Surgeon General's Report on AcQuired 
Lymphotropic Virus type III (HTLV III) and LymphadenopathyAssociated Virus (LAV), ${ }^{12}$ is transmitted through the passage of bodily fluid. The virus "has been found in blood, semen, vaginal fluids, breast milk, saliva, tears, urine, and cerebrospinal fluid. However, documented transmission has occurred only with blood, semen, vaginal fluids and breast milk."1s Although the sharing of hypodermic needles among drug users is a significant contributor to the spread of the virus, the most common means of transferring the disease is through sexual contact. ${ }^{14}$

Once a victim is infected with HIV she ${ }^{15}$ may experience flulike symptoms. ${ }^{16}$ Soon thereafter, she will become asymptomatic and will not experience any symptoms that might lead her to believe she is infected with HIV. ${ }^{17}$ The infected individual will remain

IMMUNE DEFICIENCY SYNDROME 9 (1986) [hereinafter SURGEON GENERAL'S REPORT] (stating that a person with AIDS is in "a final stage of a series of health problems" caused by HIV).

12 See id.

13 TASK FORCE REPORT, supra note 10, at 7.

14 See Richard Green, The Transmission of AIDS, in AIDS AND THE LAW: A GUIDE FOR THE PUBLIC, supra note 10, at 28, 31 (stating that " [s] exual interaction is the most common way to transmit HIV"); AIDS Update, supra note 2, at 65 (noting that over $50 \%$ of the AIDS cases reported in 1993 and 1994 involved individuals whose only risk of exposure to HIV was through sexual contact); see also State v. Gamberella, 633 So. 2d 595, 599 (La. Ct. App. 1993) (stating that "[f]or adults, the two most common forms of transmission of the [HIV] virus are sexual activity and sharing needles (in I.V. drug use) ${ }^{n}$ ).

${ }^{15}$ Throughout this Comment the HIV transmitter, or defendant, will be referred to with the male pronoun. The person contracting HIV, or the plaintiff, will be addressed with the female pronoun. The distinction is intended to make the discussion clearer. The female pronoun was chosen for the plaintiff because females engaging in heterosexual sex are at greater risk for contracting HIV than similarly situated males. See Brett-Smith \& Friedland, supra note 3, at 20 (stating that women account for " 61 percent of all cases [of HIV transmission] attributed to heterosexual contact" and noting that AIDS is having a "rising impact on women in the United States"); id. at 25 (recognizing studies showing that the recipient partners in sex, which are the women in heterosexual sex, have the highest risk of HIV infection through sexual conduct).

The heterosexual context adopted for the sake of clarity is not intended to deemphasize the impact that AIDS has had, and continues to have, on the homosexual community. Male homosexual and bisexual contact continues to be the predominant mode of HIV transmission. See AIDS Update, supra note 2, at 65 (noting that $43.3 \%$ of the AIDS cases reported in 1994 and $47.3 \%$ of the cases reported in 1993 involved individuals whose only risk of HIV exposure was "male homosexual/bisexual contact"). There have also been some reported cases linked to sexual activity between lesbians. See Brett-Smith \& Friedland, supra note 3, at 25 (recognizing that "several published cases have been attributed to lesbian sex").

${ }^{16}$ "[T] $\mathrm{T}$ his period of high viral activity seems to very short-lived, in the range of ten to twenty days." Brett-Smith \& Friedland, supra note 3, at 31.

${ }^{17}$ See id. at 33 ("Following seroconversion [(the short period of high viral activity)] 
asymptomatic for an average of ten years. ${ }^{18}$ After such time, she will develop AIDS. ${ }^{19}$

It is now sufficiently clear that all HIV-infected individuals will develop AIDS; ${ }^{20}$ when they do, they are expected to die within two years. $^{21}$ They do not, however, die from HIV itself. The effect of the virus is to impair the body's immune system by attacking white blood cells. When an HIV-infected person's $\mathrm{CD}^{+}$count $^{22}$ falls below 200, she is considered to have AIDS. ${ }^{23}$ At this point, her body will generally be unable to defend against disease. Opportunistic infections-infections that are "capable of causing disease only in a host whose resistance is lowered ${ }^{24}$-will invade the body and

most infected people completely recover their sense of health and well-being and become virtually asymptomatic.").

${ }^{18}$ See Gould, supra note 4 , at 3 (stating that "[t] he average time between initial infection and the collapse of the immune system is about ten years: death ... invariably follows within three or four years"); PHILIPSON \& POSNER, supra note 4, at 18 (stating that "the median time for conversion from the (relatively) inactive or incubation stage to full-blown AIDS is about ten years from the time the patient is infected with the AIDS virus"); see also Don Colburn, Long-Term AIDS Survivors Puzzle Scientists, WASH. POST, Jan. 31, 1995, § G (Magazine), at 7 (noting that "perhaps one in eight [persons infected] will remain AIDS-free up to 20 years after infection").

${ }^{19}$ When an individual shifts from the asymptomatic period to full-blown AIDS, she may experience nonlethal ailments. This intermediate stage was formerly labeled ARC or "AIDS-Related Complex." PHILIPSON \& POSNER, supra note 4, at 17; see also Tischler v. Dimenna, 609 N.Y.S.2d 1002, 1005 (Sup. Ct. 1994) (noting that ARC is the "viral precursor to AIDS").

${ }^{20}$ Compare Bonnie E. Elber, Note, Negligence as a Cause of Action for Sexual Transmission of AIDS, 19 U. TOL. L. REV. 923, 925 (1988) (noting that some individuals will test positive for HIV but will not "exhibit any symptoms and never progress to fully evolved AIDS") with ABA REPORT, supra note 7, at 11-12 ("Although earlier studies concluded that the disease did not necessarily and invariably result from HIV infection, a recent study of gay men suggests that all who become infected with the virus are likely to develop the disease in time.").

${ }^{21}$ See PHILIPSON \& POSNER, supra note 4, at 17 (noting that the "average interval from [AIDS] diagnosis to death is today 22 months"); Green, supra note 14, at 30 (stating that "AIDS is fatal, on average, two years after diagnosis").

${ }^{22} \mathrm{HIV}$ "enters a type of white blood cell known as the T-helper lymphocyte, which contains a specific antigen (disease-fighting agent) called CD4 (so the T-helper lymphocyte is also called the CD4 ${ }^{+}$cell)." PHILIPSON \& POSNER, supra note 4, at 16. 17.

${ }^{23}$ See id. at 18 (stating that the CDC "decided that anyone with a $\mathrm{CD} 4^{+}$cell count below 200 ... shall be deemed to have AIDS, even though some of these people are asymptomatic and many are at least free from serious disease"); see also AIDS Update, supra note 2, at 66 (noting that the CDC expanded its AIDS surveillance criteria in 1993 , including " $\mathrm{CD} 4^{+}$reporting criteria in the surveillance definition").

${ }^{24}$ STEDMAN'S MEDICAL DICTIONARY 1095 (25th ed. 1990); see also ABA REPORT, supra note 7, at 12 ("The most widely known of these opportunistic infections is a previously rare type of lung infection, Pneumocystis carinii pneumonia. The dysfunction of the immune system also causes some unusual malignancies, Kaposi's 
induce death.

Once HIV has entered the body, there is no means of preventing the onset of AIDS; ${ }^{25}$ nor is there any immunization to prevent the initial spread of the virus. ${ }^{26}$ The virus, however, is detectable. When a person is infected with HIV, her body starts to produce antibodies to fight the virus. These antibodies can be detected within one to six months of a person's exposure to HIV. ${ }^{27}$ Although the antibodies are not useful to fend off the virus, ${ }^{28}$ they are nonetheless valuable because their detection allows individuals to learn of their HIV status. Once an individual is informed of her positive HIV status, she can help reduce the spread of HIV by avoiding high-risk activities. ${ }^{29}$

sarcoma and lymphomas being the cancers most commonly described in individuals with AIDS.").

${ }^{25}$ The onset of AIDS may, however, be postponed by ingestion of Aziothymidine (AZT), see Brett-Smith \& Friedland, supra note 3, at 38-40 (describing AZT's effect on HIV), and/or 3TC, see Marlene Cimons, Combined AIDS Drug Therapy Shows Promise, L.A. TIMES, Feb. 2, 1995, at A16 (noting that "3TC, taken in combination with the commonly used drug AZT, decrease[s] AIDS infection and appear[s] to improve the immune systems of patients better than either drug used alone").

${ }^{26}$ See Larry Gostin, Traditional Public Health Strategies, in AIDS AND THE LAW: A GUIDE FOR THE PUBLIC, supra note 10, at 47,47 (stating that the virus underlying AIDS "cannot currently be prevented [by medicine] or treated").

${ }^{27}$ See PHILIPSON \& POSNER, supra note 4, at 19 ("The median time between infection and the production of detectable amounts of HIV antibodies has been estimated at 2.1 months, with 95 percent of infected persons producing detectable amounts of antibodies within 5.8 months ...." (citation omitted)); Brett-Smith \& Friedland, supra note 3, at 32 ("Blood tests usually become positive . . . within four to six weeks [of exposure], and it is estimated that at least 95 percent of those who eventually develop true infection test positive within the first six months."). Once a person tests positive for HIV, she is considered "seropositive." Seropositive is technically defined as "[t]he status of a person's blood when test results reveal HIV antibodies-as determined by two positive ELISA's and a positive Western Blot." TASK FORCE REPORT, supra note 10, at A-3 (The ELISA and Western Blot are two types of tests for the HIV antibody.).

${ }^{28}$ Unlike antibodies that combat many other communicable diseases, however, "the antibody against HIV is ineffective against the virus." Deane K. Corliss, Comment, AIDS-Liability for Negligent Sexual Transmission, 18 CuMB. L. REv. 691, 696 (1988) (citation omitted).

${ }^{29}$ See Jane H. Aiken, Education as Prevention, in AIDS AND THE LAW: A GUIDE FOR THE PUBLIC, supra note 10, at 90, 90 (stating that "[b]ecause AIDS cannot be contained by medical means such as a vaccine, people must be taught how to contain the spread of the virus through their own activity ${ }^{\prime}$ ). HIV is not very robust, and thus is unlikely to be transferred except through high-risk activity. See supra note 8 and accompanying text (describing high-risk activities). The virus can only survive in living cells; "[i]ts potency decreases greatly on drying, and it can be readily and completely inactivated by a number of commonly-used disinfectants including soaps, detergents, alcohol, and a 1:10 dilution of household bleach." TASK FORCE REPORT, supra note 10 , at 7. 


\section{TORT LAW'S DETERRENT EFFECT}

\section{A. Principles of Deterrence in Tort Law}

\section{Traditional Principles of Deterrence}

\section{As leading tort scholars have noted,}

The "prophylactic" factor of preventing future harm has been quite important in the field of torts. ... When the decisions of the courts become known, and defendants realize that they may be held liable, there is of course a strong incentive to prevent the occurrence of the harm. Not infrequently one reason for imposing liability is the deliberate purpose of providing that incentive. ${ }^{30}$

In essence, "[t]ort law is the mechanism this society uses to discourage individuals from subjecting others to unreasonable risks"31-risks that effect socially undesirable results. An underlying premise of the tort system is that individuals will become informed of the legal ramifications of their actions and will modify their behavior accordingly. ${ }^{32}$ Although some commentators have attempted to refute this assumption, ${ }^{33}$ there are theories of human behavior that support assertions of tort law's deterrent effect. ${ }^{34}$

${ }^{30}$ W. PAGe Keeton et Al., Prosser aNd KeEton ON THE LAW OF TORTS $§ 4$, at 25-26 (5th ed. 1984).

31 Donald H.J. Hermann, Torts: Private Lawsuits About AIDS, in AIDS AND THE LAW: A GUIDE FOR THE PUBLIC, supra note 10, at 153, 153. Another premise underlying our tort system is the notion that if "rules of liability [are] followed [they] will bring about, at least approximately, the efficient-the cost-justified-level of accidents and safety." Richard A. Posner, A Theory of Negligence, 1 J. LEGAL STUD. 29, 33 (1972). In the context of AIDS, the cost to society is the propagation of HIV, which is causing a strain on the social and economic structures of our society. See ABA REPORT, supra note 7, at 13.

${ }^{32}$ See Grant H. Morris, Requiring Sound Judgments of Unsound Minds: Tort Liability and the Limits of Therapeutic Jurisprudence, 47 SMU L. REV. 1837, 1850 (1994) (stating that "tort law assumes that people are aware of potential tort sanctions and alter their behavior to avoid them"); Daniel W. Shuman, The Psychology of Deterrence in Tort Law, 42 KAN. L. REV. 115, 116 (1993) (noting that "[a] credible theory of human behavior that supports the deterrence theory is a modest prerequisite to the decision to use tort law to influence human behavior").

${ }^{33}$ See Shuman, supra note 32 , at 167 ("[N]one of the mainstream theories of human behavior support the likelihood that tort sanctions appropriately deter unsafe behavior.").

${ }^{34}$ Cf. Daniel W. Shuman, Making the World a Better Place Through Tort Law?: Through the Therapeutic Looking Glass, 10 N.Y.L. SCH. J. HUM. RTS. 739, 753 (1993) (stating that "[a]lthough the architects of tort law have never explicitly addressed what theory of human behavior underlies their assumption that tort sanctions are likely to 
In the context of AIDS, society is concerned with preventing sexual episodes in which HIV is transferred. ${ }^{35}$ Society's concerns are not merely paternalistic, but rather reflect an awareness that the spread of HIV will affect future sexual partners and will act to drain our national resources. ${ }^{36}$ The proposal advocated in this Comment is designed to allocate civil liability so as to deter the transmission of HIV and to minimize the attendant individual and societal costs. The proposal does not purport to guarantee absolute deterrence on the part of any individual. Rather, it adds a marginal disincentive to engaging in risky behavior which, when applied to numerous actors, will in the aggregate reduce the frequency of unreasonably risky conduct.

Although it is nearly impossible to quantify the additional hesitancy that civil liability can induce, even small marginal disincentives can confer tremendous benefits. Because the disease spreads exponentially, ${ }^{37}$ deterring one risky sexual encounter can translate into multiple prevented transmissions. In a pandemic that

deter unsafe behavior, behavior modification or its variant, social learning theory seems the closest fit"). Even if tort law does not directly induce individuals to act in a particular way, tort verdicts publicized in the mass media may modify social mores. See NATIONAL RESEARCH COUNCIL, AIDS: SEXUAL BEHAVIOR AND INTRAVENOUS DRUG USE 290 (Charles F. Turner et al. eds., 1989) (noting that "people are less likely to behave in ways that will incur the disapproval of others in their social group; people tend to conform to the 'shoulds' and 'oughts' of behavior specified in the norms of their community"); Shuman, supra note 32, at 126 (stating that "[w]hen jury verdicts are communicated to decisionmakers it is often through word of mouth or the popular press").

${ }^{35} C f$. NATIONAL RESEARCH COUNCIL, supra note 34, at 27-28 (discussing the need for behavioral intervention).

${ }^{36}$ See Gould, supra note 4, at 205 (noting that the AIDS pandemic "means a redirection of funds to the compassionate tasks of caring for those in the terminal stages of affliction, and to the enlargement of healthcare systems already gravely overstressed"); $i d$. at 187 ("Just as a human body with some defect in the cellular units that confer protection against disease suffers by becoming diseased, so, too, when a society's individual components have immune defects, the entire society can be seen to suffer a morbid consequence." (quoting William $O^{\prime}$ Connor, M.D.)). As Professor John Mansfield notes,

All individual action bears mediately or immediately on the welfare of the community and any distinction between public and private interests is at best a matter of degree. Seizing on this truth, the law could define goals for individual and society and, in regard to all conduct, set forth rules judged likely to lead to their achievement.

Mansfield, supra note 9, at 23; see also id. at 41 (noting that informed choice may not be "found likely to lead to a socially desirable result").

${ }^{37}$ See Mortality Update, supra note 2, at 483 (presenting figures indicating the nearly exponential growth of HIV-related deaths). 
afflicted eighty thousand people in the past year alone, ${ }^{38}$ even a five percent decrease in the rate of infection would translate into thousands of lives saved. The following discussion identifies conditions that are necessary for the law to exert a deterrent influence on individual behavior.

\section{Cases Brought to Trial}

Courts cannot adjudicate cases that are not brought before them. If cases concerning the sexual transmission of HIV are not brought to trial, the courts will have no opportunity to articulate legal principles that aspire to influence behavior. There will also be no corresponding publicity to warn individuals about the potential consequences of their actions. ${ }^{39}$ Given that very few lawsuits for the sexual transmission of HIV have been brought to date, ${ }^{40}$ one might infer that courts will not have adequate opportunities to play a role in deterring individuals from spreading HIV. ${ }^{41}$ There are, however, explanations for the current dearth of negligence actions in the AIDS arena that, once explored, imply that the number of AIDS-related suits will increase in the future.

${ }^{38}$ See Laurie Garrett, Study: Saliva Stops AIDS, NEwSDAY (N.Y.), Jan. 31, 1995, at A14 (noting that "[o]ver 80,000 Americans came down with AIDS in 1994"); see also MARX E. HOMBS, AIDS CRISIS IN AMERICA 83 (1992) (writing in 1992 that "more than 100 people in the United States die of AIDS [every day], or 1 every 15 minutes").

${ }^{39}$ Although individuals may not be aware of each court decision, mass-media coverage will bring the courts' message into the home. $C f$. William L. Earl \& Judith Kavanaugh, Meeting the AIDS Epidemic in the Courtroom: Practical Suggestions in Litigating Your First AIDS Case, 12 NOVA L. REV. 1203, 1220 (1988) (warning AIDS litigators of the media attention that accompanies AIDS cases); Arthur S. Leonard, Ethical Challenges of HIV Infection in the Workplace, 5 NOTRE DAME J.L. ETHICs \& PUB. POL'Y 53, 54 (1990) (noting that by asserting their legal rights, HIV-infected persons subject themselves to publicity). This may be viewed as a second-order effect of litigation. Cf. NATIONAL RESEARCH COUNCIL, supra note 34, at 19 (stating that ${ }^{\text {" }}[t]$ he mass media can play an important role in providing information about risk ... and the norms of the community"); id. at 268 (noting that "there can be little doubt that the media play important roles in transmitting factual information and in helping to create a social climate conducive to the successful change of health-related conduct").

${ }^{40}$ The two reported cases involving causes of action for the negligent sexual transmission of HIV are Doe v. Johnson, 817 F. Supp. 1382 (W.D. Mich.) (holding that a defendant will be held liable for transmission of HIV if he had knowledge that he was infected), cause dismissed sub nom. Moore v. Johnson, 826 F. Supp. 1106 (W.D. Mich. 1993), and C.A.U. v. R.L., 438 N.W.2d 441 (Minn. Ct. App. 1989) (holding that the defendant was not liable for the transmission of HIV because it was not reasonable for him to have knowledge that he was HIV-positive in 1985).

${ }^{41}$ Even if legislatures were to enact statutes granting a private cause of action for the negligent sexual transmission of HIV, the statutes could only be enforced through lawsuits. 
Before HIV testing became common, ${ }^{42}$ individuals did not find out that they were infected with HIV until they had full-blown AIDS. ${ }^{43}$ By that time, their life expectancy was reduced to approximately two years. ${ }^{44}$ The HIV-infected individual's proximity to death presumably dampened her desire to sue. The seropositive plaintiff would have had to bear the socioeconomic costs associated with litigation, without assurance that she would reap the benefits of a favorable judgment. Even if she were able to win the suit, she would not be assured of collecting from the defendant, who himself would probably be in no condition to hold a job. As one commentator noted: "Because most individual defendants will have been ill and not working themselves, and will not have insurance for the liability of negligent transmission of an infectious disease, collecting on a judgment probably will be difficult." ${ }^{45}$

This disinclination to sue would have been equally powerful whether the plaintiff's motives were monetary or whether they were punitive, moral, or retributive. In any situation, the person who communicated the virus to the plaintiff necessarily contracted the disease before her, making it possible that by the time the plaintiff discovered her disease and initiated litigation, the defendant would either be deceased or so ill as to be indifferent to the moral ramifications of the suit. ${ }^{46}$ Furthermore, the true moral condemnation or retribution would not occur until the suit ripened to judgment, at which time the likelihood that the defendant would have died or become too ill to appreciate the ramifications of the negligence suit would be even greater. Given these facts, and the fact that

${ }^{12}$ See David P.T. Price, Between Scylla and Charybdis: Charting a Course to Reconcile the Duty of Confidentiality and the Duty to Warn in the AIDS Context, 94 DICK. L. REV. 435,473 (1990) (stating that "[a]nonymous reporting can be expected to increase the numbers of persons requesting HIV testing"); see also HOMBS, supra note 38 , at 88 (stating that 1.3 million people were tested in 1990, representing an increase in the number of low-risk individuals being tested).

${ }^{43}$ See PHILIPSON \& POSNER, supra note 4, at 23 (stating that "many peopleprimarily, of course, those who have had an HIV test and learned the (positive) result-know that they are infected (and infective) long before they become symptomatic"); Hermann, supra note 31, at 156 (stating that problems arose in lawsuits because "the plaintiff [did] not even know that he or she [was] infected until well after exposure to the virus").

${ }^{44}$ See Green, supra note 14, at 30 ("AIDS is fatal, on average, two years after diagnosis.").

${ }^{45}$ Kathryn Kelly, Negligence and Intentional Torts, in AIDS AND THE LAW 149, 159 (William H.L. Dornette ed., 1987).

${ }^{16}$ See id. at 158 (noting that ${ }^{\text {" }} \mathrm{t}$ ] he long latency period . . . makes it possible that the defendant will be deceased by the time the suit is brought ${ }^{m}$ ). 
individuals with full-blown AIDS are likely to experience reduced capacities, ${ }^{47}$ negligently infected individuals would not have been predisposed to bring costly, lengthy, laborious lawsuits in an era when the unavailability of testing increased the delay between HIV transmission and the plaintiff's discovery of her HIV infection.

Additional evidentiary and substantive obstacles have impeded suits for the negligent sexual transmission of HIV. On an evidentiary level, without access to a prompt, reliable, widely accessible method of determining one's HIV status, individuals typically did not discover that they were HIV-infected until ten years after the transmission. ${ }^{48}$ This long latency period increased the chance that the plaintiff would have had additional opportunities to be exposed to the virus, making it harder for her to prove that her contact with the defendant was the source of her infection. Indeed, if the defendant had not tested positive for HIV until after his last sexual encounter with the plaintiff, which was likely during the period before testing was common, the defendant could argue that he had contracted the disease either from the plaintiff or at some time after his last contact with her. ${ }^{49}$

On a substantive level, if the plaintiff contracted the disease before 1986, her sexual partner's conduct was probably not considered negligent. Before that year, information on HIV had not been nationally disseminated. ${ }^{50}$ The potential defendant, therefore, would have had no reason to know that he was posing a danger to the potential plaintiff. ${ }^{51}$

17 See William CuRRAN ET AL., ACQUIRED IMMUNODEFICIENCY SyNDROME: LEGAL AND REGULATORY POLICY 348 (1986) ("Incompetency among patients with HTLV-III infection is an increasingly serious problem. It is estimated that up to $40-50 \%$ of AIDS patients may have loss of higher cerebral function."); Gostin, supra note 26, at 64 ("It is estimated that 40 to 50 percent of AIDS patients may experience some loss of higher cerebral function.").

${ }^{48}$ Ten years has been the average delay between contracting HIV and entering the AIDS stage of the disease, when symptoms emerge and alert the individual to the possibility of infection. See supra note 18 and accompanying text.

${ }^{49}$ See Kelly, supra note 45, at 157-58 (stating that the blood test "proves, at most, that the defendant has been exposed at the time of the test, not that he had been at the time of his contact with the plaintiff," allowing defendants to "argue that the plaintiff had exposed her, rather than vice versa"). Unlike the other obstacles to suit, this evidentiary problem could be overcome upon a showing that the plaintiff had no other opportunity to contract HIV.

${ }^{50}$ See SURGEON GENERAL'S REPORT, supra note 11; see also Michael L. Closen, Mandatory Disclosure of HIV Blood Test Results to the Individuals Tested: A Matter of Personal Choice Neglected, 22 LOY. U. CHI. L.J. 445, 457-58 (1991) (noting that " $t$ ]he Surgeon General's pamphlet on HIV/AIDS was mailed to almost every household in the United States").

${ }^{51}$ See, e.g., C.A.U. v. R.L., 438 N.W.2d 441, 444 (Minn. Ct. App. 1989) ("Based on 
Most of the above-mentioned deterrents to bringing actions for the negligent sexual transmission of HIV, however, have decreased in recent years, and are still declining. Suspicions about one's own HIV status are arising sooner in the course of the disease as national knowledge of the symptoms of the disease increases. ${ }^{52}$ In addition, it is becoming more likely that individuals will get an HIV test when these suspicions arise. ${ }^{53}$ Thus, the gap between becoming infected and discovering one's HIV status is decreasing, making it easier for plaintiffs to isolate the particular person who infected them. This reduced evidentiary obstacle improves a plaintiff's likelihood of prevailing in a negligence suit, thus increasing the chance that she will find the filing of such a suit worthwhile.

Earlier awareness of infection increases incentives to sue in several other ways. First, the opportunity to sue at an earlier stage of the disease allows more individuals to survive until the completion of a suit, providing plaintiffs a greater opportunity to reap the benefits of monetary awards. Compounding the impact of earlier detection is the recent availability of AZT and 3TG, drugs which increase the life span of HIV-infected individuals. ${ }^{54}$ The longer life span of both plaintiffs and defendants increases the number of years in which the plaintiff may find litigation a viable option.

Second, earlier detection of the plaintiff's HIV status will mean that the defendant will also be in an earlier stage of the disease when the suit is brought. The better health of the defendant at the time of the suit makes it more likely that the defendant will still be working or will have depleted fewer of his resources on his own medical care. This fact will make it more worthwhile for the plaintiff to sue than when delayed detection and the absence of

... the information available to the general public through the time the parties ended their sexual contact, it was not reasonable for [defendant] to have constructive knowledge he might have AIDS, or that he was capable of transmitting the disease to [the plaintiff].").

${ }^{52}$ See Richard A. Knox, Awareness of AIDS Low, Expert Warns, BOSTON GLOBE, Jan. 31,1995 , at 1, 36 (stating that a recent study of 2500 newly diagnosed HIV-infected individuals revealed that more than $40 \%$ were tested before experiencing AIDSrelated symptoms). Although this Comment recognizes that significant numbers of people do not get tested until they are sick, the $40 \%$ who are tested while healthy represents a significant increase over the rates of testing in the early years of the pandemic.

${ }^{53}$ See supra note 42.

54 See NEW YORK STATE DEP'T OF HEALTH, AIDS: 100 QUESTIONS AND ANSWERS 11 (1994) (mentioning several medical practices and medications for lengthening the life of HIV-infected individuals); see also supra note 25 (discussing the effects of AZT and $3 \mathrm{TC}$ on the immune system). 
treatment left most defendants penniless and thus judgment-proof by the time of the suit.

Third, noneconomic, retributive, and moral incentives to sue also increase as earlier detection and improved treatments leave defendants healthier at the time of potential litigation. Unlike sickly defendants who might be indifferent to the consequences of having past conduct brought to public light or their assets depleted by an adverse judgment, healthier defendants are more likely to be living a superficially normal life in the eyes of colleagues and acquaintances. This may increase plaintiffs' desires to make them face the consequences of their negligent conduct. Similarly, a defendant's better health when a plaintiff discovers her infection increases the likelihood that the defendant will be continuing to place other sexual partners at risk during the time when the plaintiff is considering whether to sue. This could add a moral component to a plaintiff's outrage and desire to punish, publicize, and deter the defendant's conduct.

A final growing incentive for plaintiffs to sue is the enhanced likelihood of proving defendants' negligence, thus making suits more worthwhile for plaintiffs in general. Increasingly, the sexual contact at issue will have occurred after the national dissemination of AIDS information in $1986,{ }^{55}$ making it more likely that a jury will find the defendant negligent for failing to protect sexual partners from infection. ${ }^{36}$

Some might think that suits would be frustrated by the privacy issues $^{57}$ and confidentiality statutes ${ }^{58}$ associated with AIDS. In

${ }^{55}$ See supra note 50 and accompanying text.

${ }^{56}$ See Scott Burris, Education to Reduce the Spread of HIV, in AIDS LAW TODAY, supra note 3 , at $82,90-91$ (stating that "[s]urveys indicate that, by 1991 , most Americans were familiar with the fundamentals of AIDS: how the disease is transmitted and what people need to do to protect themselves"); see also infra text accompanying notes $79-89$ (discussing the relationship between the defendant's knowledge of his HIV infection and the duty of care he owes to his sexual partners).

${ }^{57}$ In the AIDS context, the notion of privacy includes "the right to have one's records protected from unconsented disclosure to the general public." ABA REPORT, supra note 7, at 103 (footnote omitted).

${ }^{58}$ See, e.g., Mich. Comp. Laws ANN. $§ 333.5131$ (West 1992); N.Y. Pub. Health LAW § 2785 (McKinney 1993). For several reasons, society has determined that one's medical records, as far as they relate to HIV, are private and should remain confidential. See ABA REPORT, supra note 7, at 104 (noting that confidentiality refers to private information that is revealed with the expectation that it will not be further disseminated); $i d$. at 105 (noting that confidentiality protections exist to encourage individuals to get tested for HIV antibodies and to seek and receive treatment and counseling if necessary). 
reality, however, these factors do not pose fatal impediments to AIDS litigation. Confidentiality of the defendant's medical records can be waived when other societal concerns outweigh the confidentiality interests. ${ }^{59}$ Plaintiffs' concerns about publicizing their own HIV status or sexual history in the course of litigation ${ }^{60}$ are easily addressed through procedural safeguards such as allowing anonymous suits. ${ }^{61}$ Thus, for numerous reasons, former disincentives to initiate AIDS litigation are declining, suggesting that civil litigation for the negligent sexual transmission of HIV will increase in the future.

\section{Clear and Consistent Rules}

The likelihood that an increasing number of HIV-transmission cases will occupy the legal system suggests that the courts will have an opportunity to define substantive legal principles geared toward reducing the spread of HIV. To serve its deterrent role most effectively, the law must articulate clear and consistent liability rules. ${ }^{62}$ Ambiguities in the liability standards within a jurisdiction, as well as conflicting standards among jurisdictions, leave open the possibility that a defendant could engage in risky conduct without necessarily inviting liability. Accordingly, individuals would be more inclined to engage in activities they prefer. Clearer rules would make individuals more aware of the adverse consequences of certain risky behaviors, inducing them to rethink their choices and possibly to take precautions. ${ }^{63}$

${ }^{59}$ See, e.g., Stenger v. Lehigh Valley Hosp. Ctr., 563 A.2d 531, 534 (Pa. Super. Ct. 1989), affd, 609 A.2d 796 (Pa. 1992) (applying a balancing test to determine whether the need to know HIV status outweighs privacy interests); see also ABA REPORT, supra note 7, at 106 (noting that "[c]onfidentiality may be lost in a litigation context through compliance with a subpoena or other discovery device"); SHARON RENNERT, AIDS/HIV AND CONFIDENTIALITY: MODEL POLICY AND PROCEDUREs 69-73 (John Parry \& Robert Horowitz eds., 1991) (suggesting that confidentiality be waived if a health care professional believes that a person to whom confidentiality would otherwise attach is at high risk of spreading HIV to sexual or needle-sharing partners).

${ }^{60}$ See HOMBS, supra note 38, at 129 (stating that "[b]ecause of the stigma that has been associated with AIDS, many afflicted with the disease or who are infected with the AIDS virus are reluctant to be identified with AIDS $^{n}$ ).

${ }^{61}$ See, e.g., Doe v. Johnson, 817 F. Supp. 1382 (W.D. Mich.) (plaintiff proceeding anonymously), cause dismissed sub nom. Moore v. Johnson, 826 F. Supp. 1106 (W.D. Mich. 1993); Doe v. Hirsch, 731 F. Supp. 627 (S.D.N.Y. 1990) (same).

${ }^{62}$ See Shuman, supra note 32, at 123 (stating that "[b]ecause of the importance of certainty in deterrence theory, tort law should articulate a clear, understandable standard of behavior that is communicated to decisionmakers who can then modify their behavior to avoid the tort sanctions that will otherwise accrue").

${ }^{63}$ See, e.g., D. Bruce Burlington, An Overview from the Director of the Center for 
In sum, tort law has significant potential to deter risky behavior and thus to curb the spread of HIV. All of tort law rests on the principle that legal sanctions can deter individuals from imposing unreasonable risks on others. ${ }^{64}$ In the context of AIDS, numerous factors portend an increasing incidence of potential tort suits. ${ }^{65}$ Thus, courts will be squarely confronted with issues of allocating liability in cases involving the sexual transmission of HIV. They will be charged with articulating substantive liability rules with sufficient clarity and consistency to guide parties' conduct. ${ }^{66}$ Before examining how these substantive rules can allocate liability most effectively, the following sections will explain how traditional tort principles would assign liability for the negligent sexual transmission of HIV.

\section{B. The Prima Facie Case for the Negligent Sexual Transmission of HIV}

\section{The Negligence Cause of Action}

Negligence actions bring about desired societal effects by imposing liability on those persons whose conduct "falls below the standard established by law for the protection of others against unreasonable risk of harm. ${ }^{n 67}$ To recover from a defendant alleged to have created an unreasonable risk in violation of these standards, a plaintiff must prove the following four elements of a

Devices and Radiological Health, 49 FOOD \& DRUG L.J. 175, 176-77 (1994) (stating that to ensure that regulated parties "know what is expected of them, clear and consistent criteria . . . will be established"); Brent Nicholson, Recent Delaware Case Law Regarding Director's Duties to Bondholders, 19 DEL. J. CORP. L. 573, 591 (1994) (stating that clear and consistent definitions must be developed to allow entities to "more easily determine when their duties shift"); Thomas A. Piraino, Jr., Reconciling Competition and Cooperation: A New Antitrust Standard for Joint Ventures, 35 WM. \& MARY L. REV. 871, 941 (1994) (stating that the courts' inability to develop a clear and consistent rule has "needlessly deterred" firms from certain socially desirable actions).

${ }^{61}$ See supra notes $30-38$ and accompanying text.

${ }^{65}$ See supra notes 52-56 and accompanying text (discussing evolving incentives in tort litigation).

${ }^{66}$ See supra notes 62-63. Among the benefits of the comparative knowledge proposal set forth in this Comment is its potential to cure ambiguities that pervade the current assumption of risk doctrine. The clarity and consistency benefits of this proposal are discussed infra note 214 and accompanying text.

${ }^{67}$ RESTATEMENT (SECOND) OF TORTS $\$ 282$ (1965). Other potential causes of action for the sexual transmission of HIV include "battery, fraudulent misrepresentation, negligent misrepresentation, [and] intentional infliction of emotional distress ...." Linda K. Burdt \& Robert S. Caldwell, Note, The Real Fatal Attraction: Civil and Criminal Liability for the Sexual Transmission of AIDS, 37 DRAKE L. REV. 657, 664 (1987-1988). 
prima facie negligence case:

1. A duty, or obligation, recognized by the law, requiring the [defendant] to conform to a certain standard of conduct, for the protection of others ....

2. A failure on the [defendant's] part to conform to the standard required: a breach of the duty....

3. A reasonably close causal connection between the conduct and the resulting injury....

4. Actual loss or damage resulting to the interests of [the plaintiff]. ${ }^{68}$

If the plaintiff proves each of these elements, and the defendant does not assert an affirmative defense, the plaintiff will prevail.

\section{a. Duty Owed to Plaintiff and Defendant's Breach of That Duty}

The question of duty is a legal one. ${ }^{69}$ Courts must decide whether the defendant has exercised due care to ensure that he does not "unreasonably endanger the person or property of others. ${ }^{\text {"70 }}$ Courts have applied, and commentators have discussed, the duty concept in relation to the sexual transmission of disease. They generally agree that the defendant owes a duty to everyone with whom he engages in sexual activity, ${ }^{71}$ because this is the class of persons foreseeably injured by defendant's conduct. ${ }^{72}$

The nature of the duty that the defendant owes to these sexual

${ }^{68}$ KEETON ET AL., supra note $30, \S 30$, at 164-65 (emphasis added).

${ }^{69}$ See id. § 53, at 356 (stating that duty "may be defined as an obligation, to which the law will give recognition and effect" ${ }^{\prime}$ ).

${ }^{70}$ Clark v. Dalman, 150 N.W.2d 755, 760 (Mich. 1967); see also KEETON ET AL., supra note $30, \S 31$, at 169 (stating that negligence is "conduct 'which falls below the standard established by law for the protection of others against unreasonable risk of harm'" (quoting RESTATEMENT (SECOND) OF TORTS, § 282 (1965))).

${ }^{71}$ See, e.g., Kathleen K. v. Robert B., 198 Cal. Rptr. 273, 276-77 (Ct. App. 1984) (finding that a duty exists between sexual partners who are not married, stating that "a certain amount of trust and confidence exists in any intimate relationship, at least to the extent that one sexual partner represents to the other that he or she is free from venereal or other dangerous contagious disease"); R.A.P. v. B.J.P., 428 N.W.2d 103, 107-08 (Minn. Ct. App. 1988) (noting that "[p]eople who know that they have genital herpes" must "exercise reasonable care to avoid injur[ing] . . . their potential sexual partners").

${ }^{72}$ See R.A.P., 428 N.W.2d at 107 (discussing the duties associated with herpes transmission, and stating that " $[t]$ he foreseeability of potential injury is a key factor which courts consider in establishing the scope of the legal duty to use reasonable care"); see also KEETON ET AL., supra note $30, \S 43$, at $280-81$ (addressing foreseeable risk, and noting that " $[\mathrm{i}] \mathrm{f}$ one could not reasonably foresee any injury as the result of one's act ... there would be no negligence"). 
partners includes informing them of the sexually transmissible diseases that he carries, ${ }^{78}$ giving them "full and accurate information" about the disease, ${ }^{74}$ and using protective measures to lessen the risk of transmission. ${ }^{75}$ Courts may look to common law, ${ }^{76}$ criminal statutes, ${ }^{77}$ and custom ${ }^{78}$ to determine whether this duty

${ }^{75}$ A leading case involving the sexual transmission of genital herpes discusses the general duty owed to one's sexual partner, stating that "people suffering from genital herpes generally have a duty either to avoid sexual contact with uninfected persons or, at least, to warn potential sex partners that they have herpes before sexual contact occurs." R.A.P., 428 N.W.2d at 108; see also MICHAEL L. CLOSEN ET AL., AIDS: CASES AND MATERIALS 413 (1989) (citing R.A.P.). This duty also arises in the context of diseases that are not sexually transmitted. "In an early case involving the transmission of smallpox, the court ruled that once someone was aware of his infection, a duty arose to keep away from others or to inform them of his disease so that 'they might protect themselves." Kelly, supra note 45, at 152 (quoting Hendricks v. Butcher, 129 S.W. 431, 432 (Mo. Ct. App. 1910)).

${ }^{74}$ Kelly, supra note 45 , at 152 .

${ }^{75}$ See Donald H.J. Hermann, Liability Related to Diagnosis and Transmission of AIDS, 15 L. MED. \& HEALTH CARE 36, 41 (1987); see also SURGEON GENERAL's REPORT, supra note 11 , at 17 (stating that "[i]f you[] test . . p positive [for HIV] or if you engage in high risk activities and choose not to have a test, you should tell your sexual partner; [i]f you jointly decide to have sex, you must protect your partner by always using a rubber (condom)"); Hermann, supra note 31, at 159 (noting that "requiring infected sexual partners to take reasonable precautions [through the use of civil liability] constitutes sound social policy").

${ }^{76}$ See KEETON ET AL., supra note $30, \S 32$, at 173-74 (noting that in determining whether a defendant has lived up to the "standard of conduct which the community demands," courts have "creat[ed] a fictitious person, who never has existed on land or sea: the 'reasonable man of ordinary prudence." (citing Vaughan v. Menlove, 132 Eng. Rep. 490 (1837))).

77 "The standard of conduct required of a reasonable person may be prescribed by [statute]." KEETON ET AL., supra note $30, \S 36$, at 220. As one state statute provides:

A person who knows that he or she has or has been diagnosed as having acquired immunodeficiency syndrome or acquired immunodeficiency syndrome related complex, or who knows that he or she is HIV infected, and who engages in sexual penetration with another person without having first informed the other person that he or she has acquired immunodeficiency syndrome or acquired immunodeficiency syndrome related complex or is HIV infected, is guilty of a felony.

Mich. Comp. LAws ANN. \$333.5210(1) (West 1992); see also LA. Rev. STAT. ANN. $\S 14: 43.5$ (West Supp. 1995) (prohibiting sexual intercourse by persons knowingly infected with HIV, unless such person procures informed consent from his sexual partner).

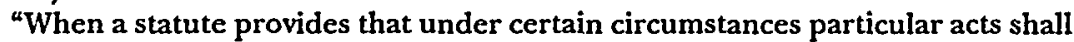
or shall not be done, it may be interpreted as fixing a standard for all members of the community, from which it is negligence to deviate." KEETON ET AL., supra note 30, $\S 36$, at 220 (footnote omitted). Statutory standards, even when technically applicable only to criminal prosecutions, can also guide and inform courts in defining minimum levels of care in civil suits. See Gostin, supra note 26, at $62-63$ (noting that criminal 
has been breached.

With respect to HIV transmission, "there exists a duty to take whatever steps a reasonable person of ordinary prudence would take to protect sexual partners from an unreasonable risk of infection." ${ }^{\text {"79 }}$ The steps a reasonable person would take are directly dependent on the degree of risk the person thinks he poses to his sexual partners. Accordingly, courts have recognized that the defendant's knowledge of his risk of being HIV-positive is an important element of defining the duty of care the defendant owes. For example, in Doe v. Johnson, ${ }^{80}$ the court classified different types of defendants according to their level of knowledge of their HIV

laws can be used to deter unreasonably risky conduct both indirectly and directly). Courts look to criminal standards for guidance in civil suits to help further the ultimate legislative goals and the "community's views" reflected in the statute. See United States v. Joseph, 37 M.J. 392, 401 (C.M.A. 1993) (concurring opinion) (stating that criminalization is a statement by a legislative body that an act is socially unacceptable); Mansfield, supra note 9, at 43 (stating that criminal law "demonstrates the strength of the community's views"); see also Gostin, supra note 26, at 62 (stating that the government uses the criminal law as a forward-looking measure aimed at deterring individuals from unacceptable future behavior that will increase the spread of HIV).

${ }^{78}$ Courts may consider custom as some evidence of the level of care that individuals should maintain. See KEETON ET AL., supra note 30, § 33, at 195 (stating that "as a general rule, the fact that a thing is done in an unusual manner [against custom] is merely evidence to be considered in determining negligence, and is not in itself conclusive"). But see id. (noting that "where common knowledge and ordinary judgment will recognize unreasonable danger, what everyone does [custom] may be found negligent" ${ }^{\prime \prime}$. Professor Keeton notes:

Since the standard [of care that sets a duty] is a community standard, evidence of the usual and customary conduct of others under similar circumstances is normally relevant and admissible, as an indication of what the community regards as proper, and a composite judgment as to the risks of the situation and the precautions required to meet them. ... If the actor does only what everyone else has done, there is at least an inference that the actor is conforming to the community's idea of reasonable behavior.

Id. at 193-94 (citations omitted).

In the area of AIDS law, it may be customary for individuals that engage in sexual activity with multiple partners to use condoms. Cf. Gould, supra note 4 , at 48 (stating that "condom use ... has soared in the last decade"). But see id. at 36 (noting that " $[\mathrm{i}] \mathrm{n}$ many parts of the United States, 70 percent of the teenage population have experienced sexual intercourse before leaving high school, and half of them use no contraception whatsoever"); Burris, supra note 56, at 91 (stating that "[o]ne study found that college undergraduates actually increased their levels of unsafe sexual behavior between 1986 and 1988, despite an increase in their general knowledge of HIV").

${ }^{79}$ Hermann, supra note 31 , at 159.

${ }^{80} 817$ F. Supp. 1382 (W.D. Mich.), cause dismissed sub nom. Moore v. Johnson, 826 F. Supp. 1106 (W.D. Mich. 1993). 
status. ${ }^{81}$ For the purposes of this Comment, both parties' levels of knowledge are grouped into the following four categories:

1. Ignorance-that is, a party does not know, or have reason to know, of her or her partner's HIV status because she never engaged in risky activity and has no reason to believe that her partner engaged in risky activity.

2. Suspicion-that is, a plaintiff suspects that the defendant could be HIV-positive, or the defendant suspects that he is HIVpositive, because the defendant has engaged in risky sexual activity.

3. Imputed Awareness-that is, the plaintiff should be aware of the defendant's, or the defendant should be aware of his own, HIV-positive status because of publicity on AIDS, and the fact that the party discovers that the defendant has physical manifestations of the disease.

4. Awareness-that is, plaintiff is aware of defendant's, or the defendant is aware of his own, HIV status, because the party is aware that defendant tested positive for HIV.

Defendants with imputed or actual knowledge or awareness would probably be liable for negligently transmitting HIV if they

${ }^{81}$ The court found that the likelihood that the defendant was posing an unreasonable risk depended on which of the following degrees of knowledge he possessed:

1) A defendant knows $s$ /he has the HIV virus because $s$ /he has been affirmatively diagnosed by a medical professional as having the disease;

2) A defendant knows that $s /$ he has the HIV virus because $s /$ he has specific knowledge of any particular facts, such as:

a) The defendant has experienced symptoms related to the HIV virus; or,

b) The defendant has come in contact with an individual, or several individuals, who have been diagnosed as having the HIV virus and defendant has engaged in conduct with such persons which results in a likelihood (or even a possibility) that $s /$ he could have the disease because of such conduct;

3) A defendant has engaged in "high risk" conduct which may result in exposure to the HIV virus, such as a great deal of unprotected sexual contact with multiple partners; [or] unprotected anal intercourse with multiple partners ....

4) A defendant has engaged in conduct which may result in exposure to the HIV virus, such as unprotected sexual relations with one partner (who had unprotected sexual relations with at least one other person).

Id. at 1388-89. The first three knowledge designations adopted by Doe are analogous to the levels of culpability espoused in the Model Penal Code (MPC): purpose (aware of existence of condition), knowledge (aware that it is practically certain that circumstances exist), and recklessness or negligence (should be aware that circumstances exist). See MODEL PENAL CODE § 2.02(2) (1985). In Doe, however, the labels denote levels of knowledge, not culpability. 
failed to protect or warn their sexual partners, because reasonable persons would not knowingly risk endangering another person's life without that person's consent. ${ }^{82}$ When a defendant possesses a lesser degree of knowledge, such as a suspicion or ignorance, other factors help resolve whether the defendant's actions were reasonable under the circumstances. These factors might include:

1. The burden the rule places on the defendant. ${ }^{83}$

2. The foreseeability that the plaintiff will be harmed. ${ }^{84}$

3. The severity of the potential harm. ${ }^{83}$

4. The net effect that the allocation of liability will have on society ${ }^{86}$

5. The parties' relationship. ${ }^{87}$

6. The moral reprehensibility of the defendant's conduct. ${ }^{88}$

${ }^{82}$ See supra notes 70-78 and accompanying text.

${ }^{83}$ See id.; see also Meany v. Meany, 639 So. 2d 229, 234 (La. 1994) (noting in a herpes transmission case that the "burden of prevention" is one factor to be considered in applying the reasonable person test to determine duty). The burden placed on defendant would be low compared with the severity of the harm of HIV transmission, because all he needs to do is say "I have AIDS" or "I may be HIVpositive because I have engaged in high-risk activity." See R.A.P. v. B.J.P., 428 N.W.2d 103, 108 (Minn. Ct. App. 1988) (stating that in the case of herpes, "the three words 'I have herpes' will be sufficient in most cases to give fair notice of the danger of infection"). Similarly, the use of a condom is easy and inexpensive, and any marginal reduction in enjoyment is far outweighed by the great decrease in the probability of transmitting or being exposed to a deadly infection.

${ }^{84}$ See Doe, 817 F. Supp. at 1387; see also Meany, 639 So. 2d at 234 (noting that in determining reasonableness, courts should consider "the likelihood of the harm").

${ }^{85}$ See Doe, 817 F. Supp. at 1386; see also Meany, 639 So. 2d at 234 (considering the "gravity of harm" when evaluating negligence).

${ }^{86}$ See Doe, 817 F. Supp. at 1391-92; see also Meany, 639 So. 2d at 234 (noting that "the social utility of the defendant's conduct" should be considered when determining negligence). This consideration might embrace the competing societal interests in individual privacy and preventing the spread of diseases. See Doe, 817 F. Supp. at 1391-92.

${ }^{87}$ See Doe, 817 F. Supp. at 1391.

${ }^{88}$ See id. at 1387. Weighing these factors to assess the negligence of the defendant's sexual transmission of HIV follows a formula fundamental to tort law. This formula, espoused by Judge Learned Hand in United States v. Carroll Towing Co., 159 F.2d 169 (2d Cir. 1947), holds that a defendant's harmful conduct violates a duty of care when the burden of preventing the harm is less than the product of the probability harm will occur without precautions and the amount of resulting injury. See id. at 173. Among the factors identified above, the first three measure, respectively, the burden of preventing HIV transmission, the probability of infecting another, and the severity of the direct harm to the plaintiff. Factor four recognizes the societal implications of liability rules relating to the spread of HIV; factor five acknowledges that duties arise in particular circumstances and are not independent of the relationship between the parties involved; and factor six acknowledges society's desire to punish those who are more culpable. 
All of these factors help to define when the defendant has breached a duty of care in his sexual contact with the plaintiff, making him liable for the HIV-associated harms he inflicts. Defendants with suspicion-those who engage in high-risk conductmay or may not be liable depending on how the court weighs the six factors previously mentioned. ${ }^{89}$ A defendant who is "ignorant" of his HIV status because he engaged in isolated acts of unprotected sex with persons whom he reasonably believed were HIV-negative would generally escape liability because the foreseeability and moral reprehensibility of his actions are low compared with the burden that would be placed on him.

Two courts have addressed the duty element in the context of the sexual transmission of HIV. The more recent is the 1993 federal district court decision in Doe v. Johnson..$^{90}$ In that case, Ms. Doe and Mr. Johnson engaged in consensual sexual behavior on the evening of June 22, 1990, and on the following morning. ${ }^{91}$ Ms. Doe claims that prior to the first sexual act, she asked the defendant to use a condom, but he refused to do so. ${ }^{92}$ She later tested positive for the HIV antibody, ${ }^{93}$ and sued seeking monetary damages for the negligent transmission of HIV..$^{94}$

The plaintiff based her negligence count on the claim that the "defendant negligently breached a legal duty he owed [her] not to transmit the HIV virus to her because he knew or should have known that he had the HIV virus. ${ }^{n 5}$ She contended that the defendant should have known that he had HIV because his "sexual[ly] active' lifestyle . . . 'put him at high risk' to contract the HIV virus." The court concluded that a duty should not attach

${ }^{89}$ See Doe, 817 F. Supp. at 1396 (holding that a defendant who engages in high-risk behavior, and who also suffers from symptoms associated with AIDS, would have a duty to take reasonable precautions to protect his sexual partners from transmission of the virus); see also id. at 1388 (characterizing unprotected sexual contact and anal intercourse with multiple partners as high-risk activities).

${ }^{90} 817$ F. Supp. 1382 (W.D. Mich.), cause dismissed sub nom. Moore v. Johnson, 826 F. Supp. 1106 (W.D. Mich. 1993).

${ }^{91}$ See id. at 1385.

${ }^{92}$ See id.

${ }^{93}$ See id.

${ }^{94}$ See id. at 1384-85. This was only one of the plaintiff's numerous causes of action. Her other claims included "Breach of duty not to transmit HIV virus ... Battery ... Fraud/Failure to warn (of HIV status) ... Fraud/Failure to warn (of sexually active lifestyle) ... Strict Liability . . . Loss of consortium [for her infant, and] ... intentional infliction of emotional distress." Id. at 1384-85.

${ }_{95}$ Id. at 1386.

${ }^{96} I d$. at 1387 (quoting the defendant's response to the plaintiff's complaint) 
to a defendant merely because he had engaged in high-risk activity. ${ }^{97}$ The court noted, however, that high-risk activity combined with possible symptoms of HIV infection would be sufficient to satisfy the duty element. ${ }^{98}$ A defendant aware of this combination of behavioral and medical indications of HIV risk would then have "a duty to act as a reasonable person under the circumstances," including the duty to "go to a medical professional, have an HIV virus test, refrain from sexual activity, warn sex partners, wear a condom during sexual contact, etc. ${ }^{99}$

The second case demonstrating the application of the duty prong of the prima facie negligence case is the 1989 Minnesota Court of Appeals decision in C.A.U. v. R.L. ${ }^{100}$ The plaintiff, C.A.U., met the defendant, R.L., in May of $1984 .{ }^{101}$ The parties engaged in sexual relations that ceased in April of $1985,{ }^{102}$ one month after the defendant sought medical help for symptoms commonly associated with HIV. ${ }^{103}$ Physicians did not inform R.L. that he might be seropositive until October of 1985; in December of 1985 the medical doctors confirmed their suspicions. ${ }^{104}$

R.L. claimed that he was not aware that the disease existed until July of $1985 .^{105} \mathrm{He}$ also claimed that he informed C.A.U. about

(alteration in original).

${ }^{97}$ See id. at 1394 (stating that " $[\mathrm{t}]$ here is no duty . . . to disclose 'high risk' activity ... without more"). The court defines high-risk activity as "unprotected anal sex; unprotected vaginal sex; unprotected oral/genital and oral/anal sex; unprotected sex with many partners; [or] having sex while drunk or high." Id. at 1390-91 (citation omitted).

${ }^{98}$ See id. at 1396. The court stated:

[I]f defendant had unprotected sexual contact with multiple partners (as is alleged) and suffered symptoms related to the HIV virus that could be construed as "common maladies" (e.g., headaches, nondescript spots on body, weakness and fatigue, shingles, etc.), then this Court would find that defendant did in fact have a duty to act as a reasonable person under the circumstances....

Id.

${ }^{99} I d$.

${ }^{100} 438$ N.W.2d 441 (Minn. Ct. App. 1989) (affirming the trial court's grant of summary judgment for the defendant on the grounds that the defendant had no actual or constructive knowledge of his infection with HIV at the time of his sexual contact with plaintiff in 1985).

${ }^{101}$ See id. at 442.

102 See id.

${ }^{103}$ See id. (noting that the defendant experienced "headaches, spots on his legs, weakness and fatigue").

${ }^{104}$ See id.

${ }^{105}$ See id. 
his condition in January of $1986 .{ }^{106}$ C.A.U., on the other hand, asserted that in April of 1985 R.L. affirmatively represented to her that he was not HIV-positive. ${ }^{107}$ C.A.U. eventually tested positive for the HIV antibody and sued to recover damages attributable to the defendant's alleged negligent transmission of the virus. ${ }^{108}$

The trial court found that R.L. did not owe C.A.U. a duty and dismissed the action on a motion for summary judgment. ${ }^{109}$ On appeal, C.A.U. argued that because her injuries were foreseeable, R.L. owed her a duty, making the dismissal below erroneous. ${ }^{110}$ She maintained that "given that [the defendant] allegedly had previous homosexual contacts, he should have known that his sexual relationship with [the plaintiff] would result in injury." ${ }^{\text {111 }}$ The court of appeals rejected this contention, stating that "[b]ased on the affidavits submitted by [the defendant's] physicians, and the information available to the general public through the time the parties ended their sexual contact, it was not reasonable for [the defendant] to have constructive knowledge he might have AIDS, or that he was capable of transmitting the disease to [the plaintiff]."112 The court did, however, agree that the proper test for determining whether a duty attaches would include the consideration of whether the harm was foreseeable. ${ }^{113}$

This duty and breach analysis highlights the element of the prima facie case most central to this Comment, which ultimately focuses on whether the plaintiff or the defendant is better situated to know of and prevent the risk of transmitting HIV. The following sections, however, will summarize the other elements of the negligence cause of action as they apply to the sexual transmission of HIV. This discussion will elucidate the factual contexts in which the courts will be deciding issues of plaintiffs' and defendants' relative knowledge of, and responsibility for, the risk of the sexual transmission of $\mathrm{HIV}$.

${ }^{106}$ See id.

${ }^{107}$ See id.

${ }^{108}$ See id.

${ }^{109}$ See id.

${ }^{110}$ See id. at 443 (noting plaintiff's contention that she had stated "a genuine issue of material fact as to whether [the defendant] should have known he was a likely carrier of the AIDS virus").

${ }^{111}$ Id.

112 Id. at 444.

113 See id. (holding that the defendant had no duty to warn the plaintiff he was HIV-positive because "at the time of the parties' relationship it was not reasonably foreseeable that he had the disease"). 


\section{b. Causation}

\section{i. Cause in Fact}

To succeed in a claim for negligent transmission of HIV, a plaintiff must prove that the defendant's actions were the cause in fact $^{114}$ and the proximate cause ${ }^{115}$ of her contracting the virus. In general, courts consider whether the defendant's act was a necessary antecedent to the plaintiff's harm in the sense that the harm would not have occurred but for the defendant's acts. ${ }^{116}$ This "but-for" test of causation in fact governs when only one person's actions contribute to the harm, as is usually the case in HIV transmission. ${ }^{117}$

114 "'Cause in fact' embraces all things which have so far contributed to the result that without them it would not have occurred." KEETON ET AL., supra note $30, \S 41$, at 265; see also id. $\$ 41$, at 269 (stating that the plaintiff must show that "it is more likely than not that the conduct of the defendant was a cause in fact of the [harm]").

${ }^{115}$ Proximate causation turns on whether the defendant's "conduct has been so significant and important a cause that the defendant should be legally responsible." Id. $\S 42$, at 273 .

${ }^{116}$ See id. $\S 41$, at 266 (noting that “[ $t$ ]he defendant's conduct is a cause of the event if the event would not have occurred but for that conduct; conversely, the defendant's conduct is not a cause of the event, if the event would have occurred without it").

${ }^{117}$ In more complex scenarios, when two or more defendants simultaneously cause a harm and either one alone would have been sufficient to do so, courts often employ the substantial-factor test. See id. $\$ 41$, at 267 (stating that the defendant's conduct is a cause in fact of the harm if his conduct is a "material element and a substantial factor in bringing [the harm] about ${ }^{n}$ ). Courts may also apply a revised version of the but-for test:

When the conduct of two or more actors is so related to an event that their combined conduct, viewed as a whole, is a but-for cause of the event, and application of the but-for rule to them individually would absolve all of them, the conduct of each is a cause in fact of the event.

Id. $\S 41$, at 268.

In the context of HIV transmission, these tests could become relevant when a plaintiff, after the initial infection, is either reinfected with HIV or is infected with another disease, such that her life is shortened by the combined effects of the two infections. See PHILIPSON \& POSNER, supra note 4, at 23 (noting that "[s]ome biologists and physicians believe that reinfection with a different strain of this highly mutable virus [HIV] places the body's immune system under additional stress and so accelerates conversion to the active disease state, thus shortening life"); see also Earle v. Kuklo, 98 A.2d 107, 109 (N.J. Super. Ct. App. Div. 1953) (acknowledging a cause of action for negligence that results in the transmission of tuberculosis); Brett-Smith \& Friedland, supra note 3, at 34 (stating that "[o]ther infectious diseases that may be related to a high-risk lifestyle (such as syphilis, hepatitis, and tuberculosis) may also become active [during the symptomatic stage of HIV] and may be more difficult to treat than they would otherwise have been in a non-HIV infected person ${ }^{n}$ ). In these complex cases, the plaintiff will die from the effects of the combination of two 
Thus, in tort actions for the negligent sexual transmission of $\mathrm{HIV}$, the plaintiff must generally prove that, but for the defendant's actions or omissions in the course of their sexual relations, she would not have incurred the harms related to HIV. ${ }^{118}$ Proving this element may present difficult evidentiary problems. ${ }^{119}$ First, a plaintiff may not discover that she is infected with HIV until years after exposure. ${ }^{120}$ Even if the plaintiff seeks an HIV-antibody test immediately after contact with the defendant, she will not get an accurate reading for up to six months. ${ }^{121}$ If the plaintiff has other partners during the six-month period, it may be difficult for the plaintiff to prove that the defendant was the cause of the viral transmission. ${ }^{122}$ It may also be difficult for the plaintiff to show

viruses; both defendants' acts could be considered substantial factors causing the plaintiff's suffering and eventual death. Similarly, the plaintiff would not have suffered in the manner she did but for the acts of both defendants. Thus, each defendant's act would be a cause in fact of the harm.

${ }^{118}$ A causal connection must exist between the defendant's negligent actions and the plaintiff's harm. See KEETON ET AL., supra note $30, \S 41$, at 263 (stating that " [a]n essential element of the plaintiff's cause of action for negligence . . . is that there be some reasonable connection between the act or omission of the defendant and the damages which the plaintiff has suffered"). For example, if a defendant's duty were to warn the plaintiff of his possible HIV infection, she would have to show that but for his failure to disclose his risk of disease, she would not have incurred HIV-related harms. This would probably require a showing that if he had disclosed his possible HIV-positive status, she would have refrained from sexual contact or would have used a condom. Such a showing requires the plaintiff to prove something inherently speculative and thus presents a significant evidentiary obstacle. To mitigate the harsh consequences for the plaintiff, the courts could treat the defendant's disclosure to the plaintiff as a defense rather than a defect in the prima facie case.

${ }^{119}$ In the AIDS context, the evidentiary difficulties in ruling out other possible sources of infection are steadily declining. See supra notes $42-52$ and accompanying text (explaining that increased use of HIV tests is reducing delay between time of HIV transmission and discovery of infection, decreasing the number of sexual partners to whom the viral contraction might be attributed).

${ }^{120}$ See Hermann, supra note 31, at 161 ("The virus may lay dormant in a person for years. It is therefore often difficult, if not impossible, to determine how long someone has been infected prior to the discovery of positive antibody status . ...").

${ }^{121}$ See supra note 27 and accompanying text (noting that HIV antibodies are not detectable until one to six months after transmission of the virus).

${ }^{122}$ Note that the plaintiff need not eliminate other possible causes to an absolute certainty, but rather need only prove by a preponderance of the evidence that the defendant was more likely than not the cause of the harm. See KEETON ET AL., supra note $30, \S 41$, at 269 ("[I]t is enough to introduce evidence from which reasonable persons may conclude that it is more probable that the event was caused by the defendant than that it was not.").

Courts can also use procedural devices to lower evidentiary barriers. For instance, a plaintiff could be permitted to name as defendants all persons with whom she had sexual contact more than six months before her HIV test. The defendants could then plead out of the suit by proving either that they are not HIV-positive or 
that she was seronegative before the encounter, ${ }^{123}$ unless she could prove that all of her prior sexual partners were HIV-negative, or that she had never previously engaged in high-risk activity. ${ }^{124}$

These evidentiary burdens can, however, be surmounted, as the court demonstrated in Berner v. Caldwell. ${ }^{125}$ The Berner court analyzed issues of causation in a claim for the negligent transmission of genital herpes. The trial court had dismissed the case on the grounds that the state did "not recognize an actionable claim for the contraction of a venereal disease under any sort of circumstances." ${ }^{126}$ On appeal, the court reversed the dismissal, relying on the plaintiff's claims "that the defendant was the only person with whom she had sexual contact; that she did not have the disease prior to their relationship; and that near the end of their relationship she discovered that she had the disease." 127 Based on these allegations, the court found that the plaintiff had raised a genuine issue of

that they were not HIV-positive when they engaged in contact with the plaintiff. The 1944 decision in Ybarra v. Spangard, 154 P.2d 687 (Cal. 1944), espoused a similar test, implying that when the plaintiff cannot know which among several defendants caused her harm, the defendants are each responsible for demonstrating that their actions were not the cause. In Ybarra, the plaintiff was injured while hospitalized and unconscious. The court stated:

The control at one time or another, of one or more of the various agencies or instrumentalities which might have harmed the plaintiff was in the hands of every defendant or of his employees or temporary servants. This, we think, places upon them the burden of initial explanation. Plaintiff was rendered unconscious for the purpose of undergoing surgical treatment by the defendants; it is manifestly unreasonable for them to insist that [the plaintiff] identify any one of them as the person who did the alleged negligent act.

Id. at 690; see also Summers v. Tice, 199 P.2d I, 5 (Cal. 1948) (placing burden of proof on two defendants where it was clear that both unintentionally shot the plaintiff and that one of the shots caused injury to plaintiff's eye).

${ }^{123}$ Unless the plaintiff were completely risk-free before the encounter with the defendant, isolating the defendant as the cause of the infection would "require[] the fortuity of either having had an antibody test close in time to the encounter with the defendant (and no intervening high-risk sex) or having had blood drawn during that same period that somehow remains available for testing." Hermann, supra note 31, at 161; see also Hermann, supra note 75, at 41 (stating that "[t]he more . . . partners the plaintiff has had, the more potential sources of virus and the greater difficulty of proving causation from a particular sexual contact").

124 See Hermann, supra note 75, at 41 ("Causation may be less easy to establish than breach of duty. Even when one can rule out transmission via contaminated blood or needles, infection from a sex partner may be hard to prove.")

${ }^{125} 543$ So. 2d 686 (Ala. 1989).

${ }^{126} \mathrm{Id}$. at 688 (noting the trial court's dismissal of the case on the defendant's motion for summary judgment).

${ }^{127}$ Id. 
material fact as to whether the defendant was the cause in fact of the plaintiff's injury. ${ }^{128}$ In effect, the court held that if a plaintiff can negate the likelihood that she contracted the disease before or after her contact with the defendant, she has established causation in fact. ${ }^{129}$

\section{ii. Proximate Causation}

The proximate cause requirement relieves defendants of liability if the consequences of their actions are too remote or unforeseeable. ${ }^{130}$ It is not difficult to prove proximate causation once duty has been established, because the criteria for assessing proximate causation are similar to those used to determine the existence of a duty. ${ }^{131}$ In the context of HIV transmission, a proximate relationship between the negligent transmission of the virus and the harms attributable to HIV will almost inevitably exist. Once the virus is transmitted it will continue to replicate; ${ }^{132}$ further stages of HIV

${ }^{128}$ See id.

${ }^{129} \mathrm{It}$ is interesting to note that a small minority of individuals believe that the only "cause" of AIDS is God's punishment for bad moral character. See Allan M. Brandt, A Historical Perspective, in AIDS AND THE LAw: A GUIDE FOR THE PUBLIC, supra note 10 , at 37,43 (stating that some individuals believe that AIDS is caused by homosexual activity rather than by transmission of a virus). Similar theories have surfaced throughout history. For instance, in 1912 one woman wrote the following about syphilis: "I knew of the disease only through newspaper advertisements [for patent medicines]. I had understood that it was the result of sin and that it originated and was contracted only in the underworld of the city." Id. at 39 (alteration in original).

${ }^{130}$ See KEETON ET AL., supra note $30, \S 42$, at 273 (stating that the "scope of liability should ordinarily extend to but not beyond all 'direct' (or 'directly traceable') consequences and those indirect consequences that are foreseeable").

131 The concepts of duty and proximate cause "are interrelated because they both involve a policy determination of whether a legal obligation should be imposed on the defendant to protect the plaintiff against the damage the plaintiff actually suffered." Johnson v. Bobbie's Party Store, 473 N.W.2d 796, 800 (Mich. Ct. App. 1991); see also Doe v. Johnson, 817 F. Supp. 1382, 1386 n.2 (W.D. Mich.) (noting that "under a negligence action, the issue whether a legal duty exists and the question of proximate cause often merge"), cause dismissed sub nom. Moore v. Johnson, 826 F. Supp. 1106 (W.D. Mich. 1993); Palsgraf v. Long Island R.R., 162 N.E. 99, 103 (N.Y. 1928) (Andrews, J., dissenting) (stating that a finding of proximate causation reflects a conclusion "that, because of convenience, of public policy, [or] a rough sense of justice, the law arbitrarily declines to trace a series of events beyond a certain point").

Despite the prevalence of policy concerns over factual realities in fixing notions of proximate cause, certain legal tests do constrain definitions of proximate causation. For instance, defendants are not held liable for harm if the harm was partially attributable to the "deliberate intervention of a third party or some extraordinary event." H.L.A. HART \& TONY HONORE, CAUSATION IN THE LAW 90 (2d ed. 1985).

132 See Brett-Smith \& Friedland, supra note 3, at 33. 
infection-including full-blown AIDS-are not only foreseeable, they are inevitable. ${ }^{133}$ A plaintiff's death from opportunistic infections is also proximately related to the infector's actions, because it is not considered an extraordinary event, but rather an unavoidable consequence of the immunosuppression characterized by HIV. ${ }^{134}$

\section{c. Real Damages}

The final element of the prima facie negligence case requires a plaintiff to prove that she has suffered actual loss or damage. ${ }^{135}$ This requirement is not difficult to satisfy in the context of HIV transmission. ${ }^{136}$ Once individuals test positive for $\mathrm{HIV}$, "it is important to monitor the status of their immune systems." 137 HIV-infected individuals are also encouraged to take AZT, ${ }^{138}$ an expensive drug that "contain[s] the damage of infection over time by limiting the reproductive activity of the virus and reducing the

${ }^{135}$ See supra notes 15-25 and accompanying text.

${ }^{134}$ Although individuals who transmit certain diseases to the plaintiff might also be liable for hastening the plaintiff's death, see supra note 117 (explaining causation analysis where multiple defendants contribute to plaintiff's harm), the defendant who transmitted HIV will not completely escape liability.

${ }^{135}$ See KEETON ET AL., supra note $30, \S 30$, at 165 (stating that "[n]ominal damages, to vindicate a technical right, cannot be recovered in a negligence action, where no actual loss has occurred" and the "threat of future harm, not yet realized," is equally insufficient).

${ }^{136}$ The Louisiana Court of Appeals decision in Meany v. Meany, 631 So, 2d 14 (La. Ct. App. 1993), rev'd on other grounds, 639 So. 2d 229 (La. 1994), illustrates the types of damages awarded in cases involving the transmission of a disease. In Meany, the plaintiff sued her former husband for negligently infecting her with genital herpes and venereal warts. The jury found for the plaintiff and awarded her the following damages:
Past and future pain and suffering
$\$ 7,500$
Past and future mental anguish
50,000
Permanent disability
10,000
Past and future medical expenses
50,000
Loss of society and enjoyment of life
TOTAL
$\$ 125,000$

Id. at 16. These types of damages are also incurred in the context of AIDS. See infra note 140 (describing harms related to AIDS). The amount and scope of damages, however, will likely be higher and broader considering the significantly greater severity of AIDS as compared with either herpes or venereal warts.

${ }^{137}$ Brett-Smith \& Friedland, supra note 3, at 34 .

${ }^{138}$ See supra note 25 (discussing the effect of AZT on HIV); see also Brett-Smith \& Friedland, supra note 3 , at 40 (stating that "[o]ver the last five years, early intervention-meaning the initiation of AZT therapy as soon as the $\mathrm{T}_{4}$ cell count drops below 500-has become the standard of care in the United States"). 
total burden of HIV in the body." 139 Once the individual begins to experience AIDS-related symptoms, medical and monitoring expenses escalate. ${ }^{140}$ The courts that have recognized actions for the sexual transmission of HIV have indicated that plaintiffs' HIVrelated injuries include "physical illness, . . . medical expenses, .. . lost wages and benefits," and a "slow, certain, and painful death." 141

\section{The Significance of the Negligence Cause of Action for the Sexual Transmission of HIV}

The emerging case law on the negligent sexual transmission of diseases indicates that "each of us has a legally enforceable duty to protect our sexual partners against the transmission of venereal and contagious diseases." ${ }^{142}$ The few cases that have addressed the standards for establishing negligence in the HIV-transmission

199 Brett-Smith \& Friedland, supra note 3, at 39. AIDS:

${ }^{140}$ One commentator provided the following example to illustrate the costs of

Imagine a forty-year-old woman. She ... has sight-threatening CMV retinitis and MAC, which causes fever and diarrhea. Her treatment for these two problems alone may require daily intravenous therapy, which she will often have to self-administer at home, and a complicated dosing schedule of three to five oral medications. She also needs PCP [pneumonia] prevention, which means either another set of pills each week or a monthly clinic visit for a breathing treatment. Of course, her treatment for HIV itself requires several daily doses of . . . AZT [or similar drugs]. Then there is her anemia, a complication of her illnesses exacerbated by the toxicities of the drugs she must take; for this, she injects a hormone under her skin three times a week. . . . Meanwhile, she must see a gynecologist every few months to monitor the abnormal Pap smears .... There is the eye doctor to be seen monthly. And then there are the visits to her primary doctor, perhaps only once a month if she is going through a "good" period; sometimes every two weeks or every week, if she is not. . . . [T] many people with HIV disease live the last months and years of their lives.

Id. at 41 .

${ }^{141}$ Doe v. Johnson, 817 F. Supp. 1382, 1385 (W.D. Mich.) (quoting plaintiff's complaint), cause dismissed sub nom. Moore v.Johnson, 826 F. Supp. 1106 (W.D. Mich. 1993); see also Hermann, supra note 75, at 41 (noting that "where transmission of the virus leads to destruction of the immune system, there will be a firm basis for damages for medical expenses and other losses").

${ }^{142}$ Hermann, supra note 31 , at 158. At the time Hermann wrote his article, there were no judicial decisions addressing the sexual transmission of HIV. His analysis is based on the transmission of other diseases; for example, he notes that a leading genital herpes case held that a defendant is liable for the transmission of the disease when he knew, or should have known, that he had the disease. See id. (citing Kathleen K. v. Robert B., 198 Cal. Rptr. 273 (Ct. App. 1984)). 
context require the defendant to act as a reasonably prudent person would under the circumstances. ${ }^{143}$ As the leading cases have noted, the defendant's degree of knowledge of the risk that he is HIV-infected is crucial in defining the precautions he reasonably should take. ${ }^{144}$ The greater the defendant's knowledge or suspicion as to his positive HIV status, the more likely it is that he will be found negligent for declining to inform his partners of the risk that he is an HIV carrier, for failing to refrain from high-risk behavior, and for neglecting to use a condom to reduce the likelihood of transmission. ${ }^{145}$

\section{The Assumption of Risk Defense}

Once a court finds that a defendant has breached a duty, it will evaluate any affirmative defenses asserted. One possible defense is assumption of risk. ${ }^{146}$ Assumption of risk, which completely bars the plaintiff's recovery, ${ }^{147}$ is successfully invoked when the plaintiff

${ }^{113}$ See Doe, 817 F. Supp. at 1386 ('[I]n Michigan the 'duty' or 'standard of care' imposed on every person, in every situation, is that of a 'reasonably prudent person.' ... That is, a defendant must always do or refrain from doing what a reasonably prudent person would do or refrain from doing."); C.A.U. v. R.L., 438 N.W.2d 441, 443-44 (Minn. Ct. App. 1989) (holding defendant to a reasonable person standard and finding that defendant's lack of knowledge about AIDS was reasonable).

144 See supra note 143; see also Doe, 817 F. Supp. at 1387-88 (noting that the duty the defendant owes to his sexual partners turns on the knowledge the defendant reasonably has as to his positive HIV status); supra notes 80.88 and accompanying text (discussing the various degrees of knowledge used to define defendant's duty to the plaintiff).

${ }^{145}$ See Doe, 817 F. Supp. at 1388 (stating that a defendant with sufficient knowledge as to his HIV status has a duty not to "engage in unprotected sexual relations, or at least warn a potential partner of the possibility that [he] may have the HIV virus").

${ }^{146}$ Assumption of risk is one of the few affirmative defenses to the negligence cause of action. The others are contributory negligence and comparative negligence. See KEETON ET AL., supra note $30, \S 65$, at 451 (stating that " $[t]$ he two most common defenses in a negligence action are contributory negligence and assumption of risk"). Contributory and comparative negligence are alternatives to one another; each jurisdiction recognizes either one of or the other. See id. $\$ 67$, at 468,471 (noting that because of " $[t]$ he hardship of the doctrine of contributory negligence upon the plaintiff" numerous states have replaced contributory negligence with comparative negligence). For a history of the assumption of risk defense, see Note, Assumption of Risk and Strict Products Liability, 95 HARV. L. REV. 872, 875-76 (1982) (stating that the assumption of risk defense emerged in the employer-employee context on the theory that employees knowingly assumed risks associated with job-related hazards, thus precluding employees from holding employers liable for accident costs); see also Mansfield, supra note 9, at 50-51 (discussing different approaches to assumption of risk in the employer-employee context in the United States and England).

${ }^{147}$ See KEETON ET AL., supra note $30, \S 68$, at 481 (noting that assumption of risk 
has agreed, implicitly or explicitly, to accept a risk imposed by the defendant. ${ }^{148}$ The plaintiff essentially forfeits her right to sue if the harm risked is later realized. ${ }^{149}$

Assumption of risk is based on the maxim volenti non fit injuria: "[ $t]$ o one who is willing no harm is done." 150 In applying this principle, assumption of risk theorists seek a balance between the desire to prevent defendants from shifting risks onto unwilling plaintiffs ${ }^{151}$ and the need to prevent plaintiffs from forcing defendants to bear the costs of risks the plaintiffs voluntarily assume. ${ }^{152}$ As Professor Mansfield explains, the law strives to protect plaintiffs by ensuring that defendants, in posing risks to others, "act only in accordance with [plaintiffs'] actual willingness." 153 The law limits defendants' liability, however, by denying plaintiffs recovery "whenever the results of [plaintiffs'] choice[s] turn[] out disadvantageously." 154 Thus, defendants are liable when they unreasonably believe that plaintiffs were willing to encounter a risk but are protected from liability when the plaintiffs are actually willing. ${ }^{155}$

The assumption of risk defense has strong libertarian overtones. It is "founded on a whole range of presuppositions thought to underlie a free society," in the sense that it permits individuals to

is "sufficient to bar the action").

${ }^{148}$ See generally id. $\$ 68$, at $480-86$ (discussing assumption of risk defense).

${ }^{149}$ See id. $\$ 68$, at 481 .

${ }^{150}$ Jane P. North, Comment, Employees' Assumption of Risk: Real or Illusory Choice?, 52 TENN. L. REV. 35, 38 n.19 (1984) (quoting KENNETH SMITH \& DENIS J. KEENAN, ENGLISH LAW 142 (2d ed. 1966)).

${ }^{151}$ See Mansfield, supra note 9, at 26 (noting that if a defendant was unreasonable in his belief as to a plaintiff's willingness to accept a risk, "then there is no reason why he should not compensate the actually unwilling plaintiff").

152 See id. at 27-28 (recognizing the "fear of deterring defendants from responding to the desires of willing plaintiffs as a justification for the assumption of risk defense, yet noting that this policy justification is not an "unyielding consideration").

153 Id. at 26.

154 Id. at 25.

155 See id. Mansfield explains:

If defendants were bound to compensate whenever the results of [a plaintiff's] choice turned out disadvantageously, they might well cease to act at all in response to the desires of willing plaintiffs. At least a plaintiff's chance of inducing action would be significantly reduced. Thus, it is to the interest of willing plaintiffs as a class that a defendant who has been induced to act by a willing plaintiff be shielded from liability.

... Unless the defendant is protected when he acts on a reasonable belief, he will tend to hold back from acting in precisely those situations in which it is to the plaintiff's interest that he should act.

Id. at 25-26. 
engage in risky behavior as long as they bear the costs associated with their actions. ${ }^{156}$ The libertarian rationale, however, has limits in the context of HIV transmission because the costs that accrue from the risk of transmission affect not only the plaintiff, but also other individuals ${ }^{157}$ and society as a whole. ${ }^{158}$ Because individuals might evaluate the costs of their own potential harm, but not the costs of societal harm, informed choice, without more, will not "likely ... lead to a socially desirable result." 159 Nevertheless, variants of the assumption of risk theory can play a vital role in the battle against AIDS. These notions of making plaintiffs bear their own costs in certain situations can be used to regulate participation in risky conduct and to allocate losses in ways that further socially beneficial goals ${ }^{160}$ such as reducing the spread of HIV.

\section{Assumption of Risk as an Independent Defense}

Before analyzing the potential of the assumption of risk defense to reduce HIV-transmission rates, it is important to define which variant of the doctrine is under analysis. ${ }^{161}$ Although the term

${ }^{156}$ Id. at 23. Mansfield notes, however, that some of these presuppositions "have been called into question or altogether discarded." Id.

${ }^{157}$ See United States v. Bygrave, 40 M.J. 839, 842 (N.M.C.M.R. 1994) ("When the HIV is passed to a specific victim, the potential exists in our society that many more victims will be infected." ).

${ }^{158}$ Procuring consent from individuals that will be affected in the future would not eliminate the harmful effects of AIDS. The spread of the disease would still drain society's medical, legal, and social systems. See Brett-Smith \& Friedland, supra note 3 , at 42 (noting that "AIDS is a resource-intensive disease that not only strains the individual's capacity to cope, but also challenges" society's ability to support these individuals); see also Mansfield, supra note 9, at 42 (stating that "[s]ociety has an interest in the well-being of its members" and that "[a]t least as far as concerns physical harm, there does not exist a sphere of individual interest where choice is sovereign no matter how great the injury and trivial the gain").

${ }^{159}$ Mansfield, supra note 9 , at 41.

${ }^{160} \mathrm{See} i d$. at 41 (noting that assumption of risk theories can be used to regulate "the control of conduct and the distribution of losses in the pursuit of broadly conceived social goals"); see also id. at 23 (asserting that because "[a]ll individual action bears mediately or immediately on the welfare of the community and any distinction between public and private interests is at best a matter of degree," it is appropriate for the law to "define goals for individual and society and . . . set forth rules judged likely to lead to their achievement").

${ }^{161}$ Although the formulation "assumption of risk" is linguistically appealing, see John W. Wade, The Place of Assumption of Risk in the Law of Negligence, 22 LA. L. REV. 5,5 (1961), it is "a doctrine more difficult to understand and apply than almost any other in the law of torts." Mansfield, supra note 9, at 17; see also Wade, supra, at 14 ("Assumption of risk often affords a quick and easy way of talking about the issue without undertaking an analysis of the total problem."). 
"assumption of risk" is sometimes used to denote a lack of duty on the part of the defendant ${ }^{162}$ or a form of comparative or contributory negligence, ${ }^{163}$ this Comment focuses on the aspect of assumption of risk that gives the defense its own unique identity. Therefore, "assumption of risk" will be used to denote an implied or express waiver of one's right to sue. ${ }^{164}$

162 When assumption of risk is equated with a lack of duty, it is said to be applied in the primary sense. See Knight v. Jewett, 834 P.2d 696, 707-08 (Cal. 1992) ('[P]rimary assumption of risk' [exists] where, by virtue of the nature of the activity and the parties' relationship to the activity, the defendant owes no legal duty to protect the plaintiff from the particular risk of harm . ..."). "Most courts recognize that [primary assumption of risk] is not truly a defense, but rather simply another way of stating that the defendant owed no duty to protect the plaintiff from the risk." Duran v. Chicago Nat'l League Ball Club, Inc., No. 88-C5239, 1989 WL 112319, at *2 n.1 (N.D. Ill. Sept. 15, 1989). As one commentator notes:

[W] here the plaintiff's awareness is likely to lead to self-protective measures and a consequent reduction of the risk, it seems appropriate to speak of a defendant's having been negligent towards a plaintiff and yet having violated no duty owing to him. He conducted himself in a way that would have resulted in liability but for some reason arising out of the informed choice of the plaintiff to encounter the risk.

Mansfield, supra note 9 , at 21.

${ }^{163}$ See KEETON ET AL., supra note $30, \S 68$, at 495 (noting that "[w]here the plaintiff acts unreasonably in [assuming the risk], it is said that [assumption of risk] is merely one form of contributory negligence"). The fact that courts do not always clearly distinguish between variations of the assumption of risk defense has generated much confusion. One commentator summarizes the reasons for courts' inability to untangle the varying views of the defense as follows:

In many of the cases in which assumption of risk appears as a possible ground for decision, a number of other grounds seeming to support the same result are also present. The phrase assumption of risk itself embraces not one but several separable concepts, but more often than not the application of any one of these concepts tends to the same result. As a consequence, there is often no particular incentive for a court to undertake the laborious task of untangling the different notions involved and pursuing each to its logical end.

Mansfield, supra note 9 , at 17-18.

${ }^{164}$ See RESTATEMENT (SECOND) OF TORTS, supra note $67, \S 496 \mathrm{~B}$ (noting that the waiver of one's right to sue if damages are later realized constitutes express assumption of risk); David J. Bederman, Contributory Fault and State Responsibility, 30 VA. J. INT'L L. 335, 348 (1990) (“[T] he doctrine of assumption of risk has . . . been seen as a denial of a duty owed to a victim because of an express or implied waiver." (footnote omitted)). In this respect, the defense resembles the consent defense to intentional torts. See Kenneth W. Simons, Assumption of Risk and Consent in the Law of Torts: A Theory of Full Preference, 67 B.U. L. REV. 213, 224 (1987) (stating that "[c]onsent . . . is the most viable concept underlying assumption of risk"); $i d$. at 248 (stating that "[a]ssumption of risk is often casually described as the doctrine of consent applied to nonintentional torts, and especially to negligence"). 


\section{The Elements of the Assumption of Risk Defense}

To establish that the plaintiff effectively waived her right to sue, the defendant must prove that:

1. The plaintiff had knowledge and appreciation of the risk,

2. The plaintiff's choice to incur the risk was free and voluntary, and

3. The actual harm to the plaintiff was within the scope of the risk assumed. ${ }^{165}$

Each of these elements will be addressed in turn.

\section{a. Plaintiff's Knowledge of the Risk}

In order to succeed in his assertion of the assumption of risk defense, the defendant must prove that the plaintiff was aware of, and appreciated, the risk imposed upon her. The standard used to measure the plaintiff's knowledge is usually a subjective one; it is not enough that a reasonable person would have known of the risk. ${ }^{166}$

The actual application of the knowledge element, however, often embraces a quasi-objective test. ${ }^{167}$ Proponents of this interpretation argue that all potential parties to AIDS suits "should be expected to know, based on the information about AIDS, that a substantial risk of contracting [HIV] exists upon engaging in unprotected sexual intercourse with a stranger."168 By imputing

${ }^{165}$ See KEETON, ET AL., supra note $30, \S 68$, at $486-87$ (describing the elements of the assumption of risk defense).

${ }^{166}$ See id. $\$ 68$, at 487 (stating that "[t]he [knowledge] standard to be applied is, in theory at least, a subjective one, geared to the particular plaintiff and his situation, rather than that of the reasonable person of ordinary prudence who appears in contributory negligence").

${ }^{167}$ See, e.g., Tuley v. Kansas City Power \& Light Co., 843 P.2d 248, 249 (Kan. 1992) (noting that ${ }^{\text {" }}[\mathrm{t}]$ he plaintiff will be held to comprehend a risk that must have been quite clear and obvious to him or her"); Olson v. A.W. Chesterton Co., 256 N.W.2d 530,538 (N.D. 1977) ("Obviousness of the danger, objectively determined, may suggest that a particular plaintiff subjectively assumed the risk of that danger . . ..").

${ }_{168}$ Harris J. Zakarin, Scared to Death: A Cause of Action for AIDS Phobia, 10 Touro L. REV. 263, 291 (1993). Information on the risk of HIV transmission was communicated in the Surgeon General's Report, disseminated nationally in 1986. See Corliss, supra note 28, at 719 (noting the cautionary wording of the Surgeon General's Report: "Unless it is possible to know with absolute certainty that neither you nor your sexual partner is carrying the virus of AIDS, you must use protective behavior." (quoting SURGEON GENERAL'S REPORT, supra note 11, at 16)).

Note that if the act in question occurred before there was widespread knowledge of the disease, the knowledge element of the assumption of risk defense would not be satisfied unless the defendant could prove that the particular plaintiff was aware 
an element of public knowledge to a particular plaintiff, quasiobjectivists imply that plaintiffs who deny such knowledge are "not to be believed, so that in effect, something of an objective element enters the case, and the standard applied in fact does not always differ greatly from that of the reasonable person." 169

As previously stated, to assume a risk, a plaintiff must not only know of the risk, but must appreciate it as well. One aspect of appreciating the risk is understanding its gravity. The law has yet to resolve the level of risk appreciation required for the assumption of risk defense. At one end of the spectrum, requiring the plaintiff to know the precise level of risk involved would vitiate the assumption of risk defense and would contradict all established definitions of risk. ${ }^{170}$ Requiring simply that the plaintiff appreciate that some risk exists, however, is equally infeasible. Any unprotected sexual encounter theoretically carries with it some risk. Requiring only minimal risk appreciation to invoke the assumption of risk defense would improperly negate liability for truly negligent defendants who, because of awareness of their possible HIV infection, pose unreasonable risks to their partners when they engage in unprotected sexual contact.

\section{b. Voluntary Assumption of Risk by the Plaintiff}

"The Maxim, be it observed, is not "scienti non fit injuria," but "volenti." It is plain that mere knowledge may not be a conclusive defence [that the plaintiff assumed the risk]. ${ }^{m 171}$ To successfully assert the assumption of risk defense, a defendant must prove (1)

of the risk. See C.A.U. v. R.L., 438 N.W.2d 441, 444 (Minn. Ct. App. 1989) (noting that a legal duty to prevent the spread of HIV did not arise because the information available in 1985 was not sufficient to warn the defendant that he was at risk of spreading the disease). This is not problematic, however, because a defendant who communicates HIV before knowledge of the disease was widespread will not likely be found negligent. See supra notes 50-51 and accompanying text.

${ }^{169}$ KEETON ET AL., supra note 30, § 68, at 488; see also Burdt \& Caldwell, supra note 67, at $678 \mathrm{n} .173$ (stating that "[s]ince AIDS and its harmful effects have been extensively publicized in the press, as well as on radio and television, the defendant should not have a difficult time showing that the plaintiff appreciated the danger of the condition").

${ }^{170}$ See Mansfield, supra note 9, at 39 (noting that requiring knowledge of the exact level of risk would demand "an exact prevision of the future that would displace any notion of risk").

${ }^{171}$ Wade, supra note 161, at $8 \mathrm{n} .17$ (quoting Bowen, L.J., in Thomas v. Quartermaine, 18 Q.B.D. 685,696 (1887)). 
that plaintiff made an assumption, and (2) that the assumption was voluntarily undertaken. ${ }^{172}$

Plaintiff's assumption, if not explicit, ${ }^{173}$ will either be impliedin-law ${ }^{174}$ or implied-in-fact. ${ }^{175}$ Implied-in-fact assumptions, the prevailing assumptions in the AIDS context, are enforced when one could reasonably infer from the plaintiff's behavior that the plaintiff had agreed to run the risk. As Professor Keeton states: "[I]f the plaintiff proceeds to enter voluntarily into a situation which exposes [her] to the risk, notwithstanding any protests, [her] conduct will normally indicate that [she] does not stand on [her] objection, and has consented, however reluctantly, to accept the risk and look out for [her]self." ${ }^{n 76}$ For example, an individual in an immunization line who holds her arm out for the doctor assumes the risks associated with immunization. ${ }^{177}$ Similarly, in the context of AIDS, if the defendant warns the plaintiff of his HIV status, and the plaintiff proceeds to engage in sexual acts with the defendant, courts will likely conclude that the plaintiff implicitly agreed "to be[] subjected to a danger of possible invasion. ${ }^{178}$

In addition to establishing that assumption of risk can be implied from the plaintiff's conduct, a defendant must also prove that the plaintiff's conduct was voluntary. In the HIV-transmission context, the defendant would have to show that the plaintiff freely

172 See KEETON ET AL., supra note $30, \S 68$, at 490 ("[T]he plaintiff is barred from recovery only if [her] choice [to incur the risk] is a free and voluntary one.").

${ }^{173}$ The plaintiff may expressly relinquish her right to sue. Contracting out of tort liability in this manner will generally be enforced by the courts, barring a statute or public policy to the contrary. See WILLIAM L. PROSSER, THE HANDBOOK OF THE LAW OF TORTS $\$ 55$, at 305-07 (2d ed. 1955); Wade, supra note 161 , at 8 .

${ }^{174}$ To say that an assumption is implied-in-law is the equivalent of saying that courts will find that the plaintiff assumed the risk regardless of the plaintiff's actual willingness to waive her legal cause of action. See, e.g., Saxton v. Hawksworth, 26 L.T. 851,853 (Ex. Ch. 1872) (stating that "if a servant enters into an employment knowing there is danger and is satisfied to take the risk, it becomes part of the contract between him and his employer, that the servant shall expose himself to such risks as he knows are consistent with the employment").

${ }^{175}$ See Walter F. Zenner, Casenote, The Interrelationship Between Design Defects and Warnings in Products Liability Law: Abbot v. American Cynamid Co., 11 GEO. MASON U. L. REV. 171, 182 (1989) (noting that assumption of risk may represent an "impliedin-fact agreement between the plaintiff and the defendant that the latter does not owe the former a duty which would otherwise exist").

${ }^{176}$ KEETON ET AL., supra note $30, \S 68$, at 490 .

177 See O'Brien v. Cunard S.S. Co., 28 N.E. 266, 266 (Mass. 1891) (noting that where a ship passenger voluntarily submits to vaccination by the ship's physician she cannot maintain an action against the ship owner for assault by the physician).

${ }^{178}$ Wade, supra note 161 , at 7. 
and voluntarily engaged in the sexual conduct that transmitted the virus. Volitional acts procured through duress or coercion will not suffice. ${ }^{179}$

\section{c. The Harm Must Be Within the Scope of the Risk Assumed}

Finally, in order to assert the assumption of risk defense successfully, the defendant must show that the harm the plaintiff suffered was within the scope of the risk that the plaintiff assumed. ${ }^{180}$ In the case of negligent transmission of HIV, this element is usually easily satisfied. ${ }^{181}$ If a plaintiff agrees to engage in sexual activity with a person she knows is infected, then she cannot claim that her contraction of HIV was outside of the scope of the risk assumed. In sum, strict application of the assumption of risk doctrine would lead one to believe that an individual in today's society who engages in unprotected consensual sexual conduct, without any assurances that the person she is involved with is HIVnegative, assumes the risk of the sexual transmission of HIV.

179 This has been a general rule of law since the landmark case of Marshall v. Ranne, 511 S.W.2d 255 (Tex. 1974). In Marshall, the plaintiff was gored by a wild boar as he ran to his car, which was parked in his driveway. The court held that the assumption of risk defense did not apply because the defendant was forcing the plaintiff to choose between two evils-remaining in his house or risking an episode with the wild boar. See id. at 260. Similarly, in the context of HIV transmission, the plaintiff does not assume the risk of HIV infection if the defendant makes her choose between two evils, one of which is risky sexual contact with him. As stated by Keeton: "Even where the plaintiff does not protest, the risk is not assumed where the conduct of the defendant has left [her] no reasonable alternative. Where the defendant puts [her] to a choice of evils, there is a species of duress, which destroys the idea of freedom of election." KEETON ET AL., supra note $30, \S 68$, at 490-91.

${ }^{180}$ In the words of the Restatement:

[A] plaintiff who fully understands a risk of harm to himself or to his things caused by the defendant's conduct or by the condition of the defendant's land or chattels, and who nevertheless voluntarily chooses to enter or remain, or to permit his things to enter or remain within the area of that risk, under circumstances that manifest his willingness to accept it, is not entitled to recover for harm within that risk.

RESTATEMENT (SECOND) OF TORTS, supra note 67, § 496C.

${ }^{181}$ See infra part III.A.3 (discussing the anomalies of the harm-within-the-risk prong). 


\section{THE CuRRENT APPROACH TO THE APPLication OF ASSUMPTION OF RISK: WHY IT IS NOT THE BEST APPROACH TO SATISFY SOCIETY'S NEEDS}

Although the assumption of risk doctrine can contribute to a reduction in the spread of HIV, its current application is not the most efficient means of accomplishing that goal. ${ }^{182}$ As one legal scholar notes, implied assumption of risk-that aspect of assumption of risk that dominates in the context of HIV transmission-causes "the greatest misapprehension and confusion as to assumption of risk, and [leads to] its most frequent misapplication." ${ }^{183}$ As currently applied, assumption of risk leads to ambiguous and inconsistent judicial decisions. ${ }^{184}$ As the facts of a given case stray from the most simplistic fact patterns, the predictability of judicial decisions decreases. This is problematic for two reasons. First, inconsistent decisions frustrate tort law's ability to effect deter-

${ }^{182} C f$. Simons, supra note 164, at 214 (noting that the "traditional doctrine [of assumption of risk] deserves sharp revision, but not necessarily abolition").

${ }^{183}$ KEETON ET AL., supra note 30, at 484.

${ }^{184}$ Justice Frankfurter explains the source of this confusion in Tiller v. Atlantic Coast Line R.R., 318 U.S. 54 (1943) (Frankfurter, J., concurring), stating:

[T]he phrase "assumption of risk" is an excellent illustration of the extent to which uncritical use of words bedevils the law. A phrase begins life as a literary expression; its felicity leads to its lazy repetition; and repetition soon establishes it as a legal formula, undiscriminatingly used to express different and sometimes contradictory ideas.

Id. at 68.

Under the current tort regime, assumption of risk creates additional confusion when it is not clearly distinguished from contributory negligence. See Samuel R. Guelli, Case Note, Tort Law: The Status of Assumption of Risk in Product Liability in Ohio After Cremeans v. Willmar Henderson Mfg., 566 N.E.2d 1203 (Ohio 1991), $18 \mathrm{U}$. DAYTON L. REV. 243, 246 (1992) (noting that confusion abounds because voluntary and unreasonable encountering of a known risk is often intermittently labeled as contributory negligence or assumption of risk); see also Rosas v. Buddie's Food Store, 518 S.W.2d 534, 539 (Tex. 1975) (recognizing that assumption of risk "has generated so many elusive distinctions that precedent is often of little help"); Robert L. Spell, Stemming the Tide of Expanding Liability: The Coexistence of Comparative Negligence and Assumption of Risk, 8 MISS. C. L. REv. 159, 162 (1988) (stating that "[t]he confusion [surrounding the application of assumption of risk] has been fueled, in part, by the failure of the courts and commentators to recognize a consistent usage of assumption of risk"). 
rence. ${ }^{185}$ Second, such decisions often place the burden on the less deterrable person. ${ }^{186}$

The following sections discuss the reasons why courts are not able to apply the assumption of risk defense consistently in its current form. These reasons can be grouped into two general categories. First, the interpretation of the elements of the defense varies considerably. Second, a literal application of the present form of assumption of risk would lead to undesirable results.

185 Varying the defense on a case-by-case basis may lead to favorable results in some instances. As one commentator notes, assumption of risk

is not clarified by being tied too closely with "consent," "voluntary," "knowledge," and "appreciation." Each of these terms is also a variable, inconstant and unstable, meaningful only in the light of the factual and environmental context of the particular case, and can only frustrate judgment if given or attempted to be given a stable or static content of meaning. It is not here suggested that this easy convertibility of doctrine and the instability of its vocabulary are disadvantageous, or are to be condemned. On the contrary, the inability to achieve a uniformity of terminology and usage may well be the very factors in the judicial process that insures the freedom of a court to reach a just or at least an acceptable result in the particular case.

Leon Green, Assumed Risk as a Defense, 22 LA. L. REv. 77, 78 (1961) (emphasis added). The inconsistency in the application of the defense is problematic, however, when the tort system is being used to affect social behavior. Mansfield advocates a clear legal test for assumption of risk:

Results merely sensed to be right, even if they are right, lack that quality of reasonableness necessary for acceptable law-making. They contribute nothing to the upbuilding of a structure of general thought within which the solution of genuinely difficult problems can succeed. . . . When such [legal] concepts are not developed, the courts necessarily continue on a purely ad hoc basis, with the injustices that this mode of decision can breed.

Mansfield, supra note 9, at 18. Individuals will not be apprised of the acts that are condoned and admonished by society and, as a result, they will not modify their behavior accordingly. See supra note 62 and accompanying text (discussing the effect that clear and consistent rules have on individual action).

${ }^{186}$ There are two ways in which inconsistent court decisions will result in instances in which the burden is placed on the party who is less deterred. First, instead of reinforcing broadly accepted societal norms, some courts will expand the elements of the defense to reach decisions that appear just. Second, other courts, attempting a literal translation of the assumption of risk doctrine, may hold a plaintiff liable based on her knowledge that HIV exists and that no one is immune. See supra note 168 and accompanying text (discussing the quasi-subjective interpretation of the assumption of risk knowledge element). Such conclusions may run counter to the fact that the defendant was in the best position to avoid the HIV transmission. 


\section{A. Varied Interpretations of the Assumption of Risk Elements}

\section{Ambiguity in the Definition of Knowledge}

Although courts generally agree that the knowledge requirement for the assumption of risk defense is more subjective than the reasonable person standard, they do not agree on the level of subjectivity required. At one end of the spectrum, commentators advocate a purely subjective test. Donald Hermann articulates this view, warning that courts cannot properly assume or require that "common knowledge be included in any given person's knowledge. ${ }^{187}$ Thus, in the context of HIV transmission, subjectivists maintain that the defendant cannot successfully assert that the plaintiff assumed the risk unless the defendant fully disclosed his HIV status and the nature of the virus. ${ }^{188}$ Under this view, the prevalence of information on AIDS should play no role in determining whether a person knew of the risk of HIV infection associated with sexual behavior.

In practice the knowledge standard is often applied less strictly. ${ }^{189}$ The plaintiff's assumption of the risk is judged accord-

${ }^{187}$ Hermann, supra note 75, at 42 (noting that a "question arises whether a person who consents to sexual relations implicitly assumes the risk of contracting AIDS, given the widespread knowledge of the nature of the disease and the means of transmission," but concluding that only subjective knowledge should constitute assumption of the risk).

${ }^{188}$ See, e.g., Kelly, supra note 45, at 155 ("[T] that [he] made full and accurate disclosure of [his] disease and its contagiousness in order to demonstrate that a plaintiff consented . . . or assumed the risk of infection under a negligence theory.").

${ }^{189}$ In fact, the 1993 decision of Doe v. Roe, 598 N.Y.S.2d 678 (J. Ct. 1993), illustrates a court's willingness to consider employing a fully objective test. In Doe, the defendant transferred chlamydia to the plaintiff, her former boyfriend. See id. at 679. The court discusses the assumption of risk defense in dicta, stating that:

A person assumes the risk where he voluntarily subjects himself to a peril known to him or generally observable by a person of ordinary prudence in his situation.... In the same vein, persons who engage in unprotected sex, at a time of the prevalence of sexually transmitted diseases, including some that are fatal, assume the risk of contracting such diseases. Both parties in an intimate relationship have a duty to adequately protect themselves. When one ventures out in the rain without an umbrella, should they complain when they get wet?

Id. at 681 . One could reasonably infer from the court's language that it would apply the assumption of risk doctrine to the sexual transmission of HIV regardless of a plaintiff's actual knowledge or awareness of the risk. On this basis, the assumption of risk defense could potentially eviscerate the cause of action for the negligent 
ing to "whether a reasonable person in defendant's shoes would believe that plaintiff had (subjectively) consented, not whether a reasonable person in plaintiff's shoes would have consented."190 There are also "some things ... which are so far a matter of common knowledge in the community, that in the absence of some satisfactory explanation a denial of such knowledge simply is not to be believed." 191

Accordingly, the law must define a principled threshold of risk appreciation which shifts legal responsibility back onto the plaintiff. Infinite variations of the indicia of risk which might become known to the plaintiff make this line drawing difficult. For example, a defendant may inform a plaintiff that he falls in one high-risk group, when he actually falls in two. ${ }^{192}$ The latter may work to double the plaintiff's chance of contracting HIV. The question then arises as to whether the plaintiff appreciated the risks involved in having sexual relations with the defendant. ${ }^{193}$ The current assumption of risk defense leaves these difficult issues of measuring knowledge and appreciation of risk unresolved.

\section{Differences in the Definition of Voluntary}

The interpretation of "voluntary" encompasses two layers of confusion. First, although many courts define voluntariness as a lack of coercion, some find that there must be "actual willingness to accept the risk. ${ }^{n 194}$ Second, courts cannot agree on a definition for coercion.

This second level of confusion creates a distinct set of intricate problems. For example, some legal theorists call for an abolition of the distinction between coercion caused by the defendant and

transmission of sexually transmitted diseases.

${ }^{190}$ Simons, supra note 164, at 252; see also Meistrich v. Casino Arena Attractions, 155 A.2d 90, 94 (N.J. 1959) (noting that actual knowledge of a risk is not required; assumption of risk can be "applied to a risk which a reasonable [person] would have detected").

191 KEETON ET AL., supra note $30, \S 68$, at 488.

${ }^{192}$ A plaintiff would assess the risk as being considerably higher if, for instance, defendant had engaged in both unprotected sex with multiple partners and intravenous drug use, as opposed to only one of the two.

${ }^{193}$ Although this question highlights an open issue in tort law, the query is by no means novel. See Russo v. The Range, Inc., 395 N.E.2d 10, 13-14 (Ill. App. Ct. 1979) (differentiating between types of harms based on the ways in which they are realized, stating that "it is possible to infer that Russo's ride down the slide was an abnormal occurrence caused by some danger unknown to him and a risk he did not assume").

${ }^{194}$ Wade, supra note 161 , at 8. 
coercion caused by other forces. ${ }^{195}$ This problem becomes particularly acute in the context of AIDS because duress may be effected by a number of mechanisms outside the defendant's control. ${ }^{196}$ For example, the plaintiff may become intoxicated before her encounter with the defendant. ${ }^{197}$ In such cases society may want to hold the defendant liable for his actions because "the risks are high and the plaintiff so much at the mercy of the defendant, that the law deems it best to forbid the defendant to act in a dangerous manner, even though the plaintiff is willing that he should."198

195 See ALAN WERTHEIMER, COERCION 40 (1987) (noting that one commentator "maintains that when someone consciously takes advantage of another's adversity, 'the fact that he did not create [the situation] should be treated as of little importance" (citation omitted)). Samuel Williston addresses this theory in the context of contract law, stating that "if such circumstances were known[,] and advantage taken of them by the other party, a degree of pressure which would not ordinarily amount to duress may be deemed to have such a coercive effect as to invalidate a transaction." 13 SAMUEL WILLISTON, A TREATISE ON THE LAW OF CONTRACTS $\S 1608$, at $682-83$ (3d ed. 1970).

The threshold level of duress that must be met to invalidate an assumption of risk is lower than that required to vitiate a victim's consent in the criminal act of rape. See MODEL PENAL CODE $§ 213.1$ (Proposed Official Draft 1962) (stating that a person is guilty of rape if he procures sexual intercourse by physical force, by threatening anyone with imminent death, serious bodily injury or pain, or kidnapping, or by substantially impairing a person's ability to control their actions through the use of drugs, intoxicants, or the like).

${ }^{196}$ More than one commentator have gone as far as to suggest that a female may be "coerced" by a male's implicit threat to deny her status: "Status can be a motive for dating and for engaging in unwanted sex in dating relationships. In a recent pilot study, for example, several women described having sex with a man to keep him in the relationship because of the status he conveyed." Charlene L. Muehlenhard \& Jennifer L. Schrag, Nonviolent Sexual Coercion, in ACQUAINTANCE RAPE: THE HIDdEN CRIME 115, 119 (Andrea Parrot \& Laurie Bechhofer eds,, 1991). The courts will not likely recognize this form of coercion, however, unless the woman "has a baseline entitlement to [the man's] companionship." Donald A. Dripps, More on Distinguishing Sex, Sexual Expropriation, and Sexual Assault: A Reply to Professor West, 93 Colum. L. REV. 1460, 1466 (1993).

197 This scenario is commonly played out on college campuses. See Gould, supra note 4 , at 52 (noting that " 80 percent of sexual relations among college students involve alcohol"). The use of alcohol in sexual relations not only affects an individual's ability to make an informed decision, but it also "weakens the immune system and thus makes the [alcohol] abuser more susceptible to HIV infection." PHILIPSON \& POSNER, supra note 4, at 83.

${ }^{198}$ Mansfield, supra note 9, at 50 . There may be instances where the plaintiff was not coerced, but there was still a lack of conscious choice. Should "actual choice and the opportunity for choice have the same legal consequences?" Id. at 37 . There may be cases when a participant does not decide that the sexual experience is worth the risks, but merely acts as a passive participant who goes through the sexual experience without having made a conscious choice. Cf. id. at 36 (differentiating between circumstances in which a soldier weighs the alternatives of moving into enemy 
A second difficulty courts have found in defining coercion is that a plaintiff may be susceptible to coercion by nature. ${ }^{199}$ "Natural" coercion is especially problematic in areas of tort law involving sexual acts because of the physiological effect sex has on the body: "Sex can be defined fairly adequately in physiological terms as consisting of the building up of bodily tensions and their release. ${ }^{200}$ Once bodily tensions reach a threshold level, the plaintiff may be less able to exercise free will. ${ }^{201}$ Although most courts will not adopt an approach that would allow parties to claim coercion by nature, ${ }^{202}$ the flexibility in the current doctrine would legitimize such an interpretation.

\section{Confusion Surrounding Harm Within the Risk}

In the context of sexual relations, courts may experience difficulties in determining the exact scope of risk assumed by the plaintiff. In general, the types of risk one assumes by engaging in sexual intercourse include the transmission of venereal diseases, the

territory, and when he allows himself to get carried to the line with the charge of soldiers). This type of situation presents a nuance of the assumption of risk doctrine that will not be explored in this Comment.

${ }^{199}$ In the sexual realm, "we're all puppets, and our best hope for even partial liberation is to try to decipher the logic of the puppeteer." ROBERT WRIGHT, THE MORAL ANIMAL 37 (1994); see also STEPHEN FROSH, SEXUAL DIFFERENCE: MASCULINITY AND PSYCHOANALYSIS 104 (1994) (stating that " [s]ex is always there, an obsession, but it is not part of us; being repudiated and repressed, it paradoxically threatens to take control").

${ }^{200}$ MAY, supra note 1 , at 73 .

201 See RoNALd DE Sousa, The Rationality of Emotion 199 (1987) (defining akrasia (weakness of the will) as "doing something intentionally that one has overriding reasons not to do" (emphasis omitted)). This may be particularly true if the plaintiff is a male. See FROSH, supra note 199, at 99 (describing "the overwhelming drive of male sexuality" (quoting ARTHUR BRITTAN, MASCULINITY AND POWER 47 (1989))); WRIGHT, supra note 199, at 30 (stating that "there can be no doubt that sexual feeling in the female is in the majority of cases in abeyance . . . and even if roused ... is very moderate compared with that of the male" (quoting STEVEN MARCUS, THE OTHER VICTORIANS: A STUDY OF SEXUALITY AND PORNOGRAPHY IN MID-NINETEENTH-CENTURY ENGLAND 31 (1974))).

${ }^{202}$ As one commentator notes:

The moral message is clear. To be human is to rise above the chain of natural causality and to strive towards a meaningful autonomy. It is to choose one's own values and then to attend to the implications of coherently holding to them. For only if they are coherently followed do values function as components of the personality. And only as a personality, that is a thing with dignity, integrity and autonomy, is one human.

STUART TOdDINGTON, RATIONALITY, SOCIAL ACTION AND MORAL JUdGMENT 42 (1993). 
spread of HIV, and pregnancy. The plaintiff, however, may not assume the risk of each of these effects in every act of sexual intercourse. For example, if a woman is informed that her male partner is sterile, she does not assume the risk of pregnancy. ${ }^{203}$ Similarly, if a plaintiff is assured by the defendant that he is HIVnegative, the scope of the risk assumed would not include the transmission of HIV.

Although this analysis appears simplistic, there may be gray areas involved in determining whether the harm is within the scope of the risk assumed. The following hypothetical describes an improbable fact scenario that illustrates this confusion: A plaintiff, assuming the risk of the sexual transmission of HIV, may engage in sexual intercourse with a defendant. To excite his partner, the defendant may unilaterally decide to poke the plaintiff's back with a needle. It is then possible that the plaintiff would contract HIV from the needle rather than from the intercourse. Although plaintiff assumed the risk of HIV transmission, she assumed this risk through sexual intercourse, not through the needle puncture. The harm, HIV transmission through a needle puncture, was not within the scope of the risk assumed. Note, however, that if one defines the harm as "HIV transmission" instead of "HIV transmission through a sexual episode," then the harm was within the risk assumed. This presents an anomaly which, although recognized, is not adequately addressed by the courts. The harm-within-the-risk analysis varies with the court's definition of risk, ${ }^{204}$ thus contri-

${ }^{203}$ The plaintiff also may not assume the risk of HIV transmission if her partner has acellular semen. See United States v. Perez, 33 M.J. 1050, 1053 (A.C.M.R. 1991) (quoting the defense expert's testimony that the fact that the defendant had "a vasectomy and the fact that he ha[d] not transmitted the virus either to his wife or to other sexual partners ... [indicates that defendant] can't transmit the virus because he has an acellular semen specimen" (emphasis omitted)); id. at 1052 ("[T]he ... likelihood of [HIV] infection being spread by genital secretions is related to the number of cellular elements in that fluid"' (quoting Dr. Tramont of Walter Reed Army Medical Center, defense counsel's expert witness)). But see id. (noting that the expert witness was never asked the "pertinent" question, that is "what effect a vasectomy has on the ability of a HIV-positive male to transmit the AIDS virus in vaginal sexual intercourse" $)$.

${ }^{204}$ As one court states:

It is apparent that when the risk is defined more narrowly, . . . the analysis of voluntariness changes. . . . Appellant was familiar with varsity football and he voluntarily participated in it, but it does not follow that he voluntarily participated in jungle football if such participation was required to make the varsity team. ... Another way to put this is that the voluntariness of appellant's act must be proximately related to the danger (or the risk) which caused the injury. Otherwise, the question of voluntariness, which is said 
buting to the confusion surrounding the current assumption of risk doctrine.

\section{B. Literal Interpretation of the Current Assumption of Risk Doctrine Leads to Undesirable Results}

Another reason why the current assumption of risk doctrine encourages inconsistent decisions is that courts, realizing that a literal interpretation of the doctrine will lead to unjust results, manipulate the doctrine to achieve equitable outcomes. ${ }^{205}$ Calahan v. Wood illustrates this reformulation. ${ }^{206}$ In Calahan, the plaintiff sought a ride home from her co-worker. When the coworker's car did not start, a few people pushed the car out onto a public highway. The plaintiff remained in the car after the participants realized that they would not be able to start the vehicle. Soon thereafter, the car was struck in the rear by the defendant who claimed that he could not see the car because of fog. ${ }^{207}$

Applying the assumption of risk doctrine literally, one would conclude that the plaintiff assumed the risk as to both plaintiff's and defendant's conduct: plaintiff admitted that she knew "that it was dangerous stopping a vehicle on a highway at night; ${ }^{208}$ her conduct was voluntary; and, the harms associated with rear-end

to be at "the basis" of assumption of risk . . . would be avoided, for the only relevant voluntariness is voluntariness related to the risk.

Rutter v. Northeastern Beaver County Sch. Dist., 437 A.2d 1198, 1208 (Pa. 1981) (citation omitted). David DeWolf and Deborah Hander have analyzed this and similar cases, concluding that:

When the risk is defined broadly ("those who play football are likely to get hurt"), the average high school player voluntarily assumes [the risk]. On the other hand, when the risk is defined narrowly ("those who play football for a coach with less than the recommended twelve hours of training in injury prevention") then the average player will almost never be aware of the risk and, thus, will not be. said to have assumed it.

David K. DeWolf \& Deborah G. Hander, Assumption of Risk and Abnormally Dangerous Activities: A Proposal, 51 MONT. L. REV. 161, 181 (1990); see also id. (noting that courts operating within the bounds of the current assumption of risk test "cannot meaningfully distinguish between those cases in which the plaintiff should recover all and those cases in which she should recover nothing").

${ }^{205}$ One court recapitulated this view, stating that " $[t]$ he expression assumption of risk is a very confusing one. In application it conceals many policy issues, and it is constantly used to beg the real question." Russo v. The Range, Inc., 395 N.E.2d 10, 12 (Ill. App. Ct. 1979) (quoting Barrett v. Fritz, 248 N.E.2d 111, 115 (Ill. 1969)). ${ }^{206} 465$ P.2d 169 (Utah 1970), overruled on other grounds by Randle v. Allen, 862 P.2d 1329 (Utah 1993).

207 See id. at 170 .

${ }^{208} \mathrm{Id}$. 
collisions were clearly within the scope of the risk assumed. Although this result follows from doctrinal application, the court stated:

Generally, a guest by accepting a ride in an automobile does not assume the risk of injury caused by the negligence of users of the highway other than his host, unless the acts of the host in which the guest acquiesces operate as a contributory cause of the collision. ${ }^{209}$

The court implicitly recognized the tension between the law generally espoused by courts and the doctrine of assumption of risk.

Leading commentators also recognize that the current form of assumption of risk does not readily lead to the results that courts desire. Professor Keeton notes:

A pedestrian who walks across the street in the middle of the block, through a stream of traffic traveling at excessive speed, cannot by any stretch of the imagination be found to consent that the drivers shall not use care to watch for him and avoid running him down. ${ }^{210}$

This is true even though the conventional elements of assumption of risk are satisfied. ${ }^{211}$ As in other contexts, a literal interpretation of the assumption of risk doctrine in AIDS cases will not lead to socially desirable results. Such interpretation will not always place the burden on the more deterrable party, and thus will not further the effort to decrease the spread of HIV.

\section{Comparative KNowledge: A Proposal For the APPLICATION OF THE ASSUMPTION OF RISK DEFENSE TO THE SEXUAL TRANSMISSION OF HIV}

Any new formulation of the assumption of risk doctrine should: (1) maximize the reduction in the spread of HIV and (2) be clearly stated so as to allow for consistent application. An assumption of risk defense based on a comparative knowledge standard, contrasting the defendant's and the plaintiff's relative knowledge of the defendant's HIV status, rather than relying on the plaintiff's absolute knowledge alone, satisfies both of these requirements.

This section proposes a comparative knowledge formulation for assumption of risk and explores the rationale for making liability

\footnotetext{
${ }^{209}$ Id. at 171.

${ }^{210}$ KEETON ET AL., supra note $30, \S 68$, at 485 .

${ }^{211}$ See id.
} 
dependent on relative degrees of knowledge. The discussion then demonstrates how both policy considerations and other areas of the law support the consideration of comparative knowledge. Finally, this section addresses potential arguments against adopting a comparative knowledge standard.

\section{A. Comparative Knowledge-A Theory}

Judges applying the comparative knowledge test proposed in this Comment should apply the voluntary prong, ${ }^{212}$ the assumption prong, ${ }^{213}$ and the harm-within-the-risk prong ${ }^{214}$ of the assumption of risk defense liberally. The voluntary element should be considered satisfied if the plaintiff was not forced to engage in the sexual act. The plaintiff's assumption should be satisfied by the mere fact that the plaintiff engaged in risky behavior. HIV transferred by semen or vaginal fluids should be considered within the scope of the risk assumed by one who voluntarily comes into sexual contact with another's genitals. By interpreting these three elements liberally and consistently, ${ }^{215}$ courts will establish bright lines separating cases in which the plaintiff has assumed the risk from those in which she has not. Furthermore, a liberal interpretation will include more plaintiffs within the assumption of risk framework, allowing the assumption of risk doctrine to turn on the knowledge element-the element most closely linked to deterrence.

With respect to the knowledge prong, courts should not inquire, as they currently do, into whether the plaintiff had knowledge of the defendant's HIV status. Instead, courts should employ a comparative knowledge approach that would consider the difference between the plaintiff's and the defendant's levels of knowledge. Assumption of risk should be a viable defense only when the plaintiff's knowledge of the defendant's HIV status is equal to or greater than the defendant's knowledge. The following discussion will demonstrate why the costs of HIV transmission should be allocated to the party with greater knowledge.

${ }^{212}$ See supra notes $174-78$ and accompanying text (discussing the voluntary nature prong of the assumption of risk defense).

${ }^{213}$ See supra note 179 and accompanying text (discussing the assumption prong of the assumption of risk test).

${ }^{214}$ See supra part II.C.2.c (discussing the harm-within-the-risk prong of the assumption of risk test).

${ }^{215}$ See supra part II.A.3 (discussing the benefit of consistent rules). 
If the law is to effectively deter individuals from engaging in HIV-transmitting behavior, it must take into account the factors that motivate individuals to partake in or abstain from such behavior as well as the net effect of liability allocations. ${ }^{216}$ Several predominant motivational factors include fear of death, ${ }^{217}$ conformance with morality, ${ }^{218}$ and susceptibility to stigmatization. ${ }^{219}$ The

${ }^{216}$ The proposal advanced in this section assumes that individuals are rational actors. Intuitively, sexuality seems to be driven by impulsive, somewhat irrational forces. Even when driven by impulse, however, human beings can be considered rational as long as they can weigh considerations and form reasoned, albeit poor, judgments. See K.D. Irani, Introduction: Modes of Rationality, in RATIONALITY IN THOUGHT AND ACTION at xi, xi (Martin Tamny \& K.D. Irani eds., 1986) ("Rationality is ordinarily taken to be that characteristic of human beings which makes their thinking consistent and reliable, that aspect in particular which deals with inferences, judgments, and decisions. "); Raphael Stern, Modalities, Rationality, and Intervention, in RATIONALITY IN THOUGHT AND ACTION, supra, at 261, 262 (stating that "if someone is behaving rationally, then, at least, he or she will, or can, consider alternatives").

Rationality is an important premise in both the formulation and the application of legal rules. See, e.g., YVES R. SIMON, PHILOSOPHY OF DEMOCRATIC GOVERNMENT 109 (1951) (noting that the law's persuasive power is "to awaken . . . voluntary inclination toward a certain course of action"); Samuel D. Cook, Coercion and Social Change, in CoERCION 107, 112 (J. Roland Pennock \& John W. Chapman eds., 1972) (stating that individuals "at times, have to be compelled to limit their wills, actions, and desires and to recognize the rights and claims of others").

The fact that individuals choose to use condoms in sexual activity is some proof of their rational thought processes:

$[\mathrm{T}]$ he use of condoms by adolescents has been found to be correlated with factors related to rational choice, such as confidence in being able to use a condom correctly (positive correlation), perceived cost of using a condom (negative), and perceived risk of contracting AIDS if a condom is not used (positive) ....

PHILIPSON \& POSNER, supra note 4, at 69 (citation omitted). It will be assumed for the purposes of this Comment that individuals have enough free will to be able to choose whether or not to succumb to the power of nature.

${ }^{217}$ One commentator describes the manner in which individuals deal with death:

[T]he fear of death ... is notorious for the efforts philosophers have exerted to prove it irrational. The fear of death underscores some of the problems surrounding the rationality of emotions, for it does not appear to vary in relation to the certainty of death, which is constant. Yt depends on other factors, including its envisaged closeness in time. And what could that have to do with rationality?

DE SOUSA, supra note 201, at 5.

${ }^{218}$ See, e.g., PHILIPSON \& POSNER, supra note 4, at 98 (arguing that altruists will not generally engage in unprotected sex after testing positive for HIV, whereas egoists will not likely engage in safe sex once they learn that they have been infected); $i d$. at 107 (stating that persons who are in high-risk groups have been moving toward safer sex).

${ }^{219}$ See NATIONAL RESEARCH COUNCIL, supra note 34, at 27, 393-99 (discussing the stigmatization surrounding the AIDS pandemic). 
more these factors affect an individual's decision-making process, the less likely the individual will be to engage in high-risk sexual behavior. Thus, increasing levels of these motivational factors will correlate with increasing levels of deterrence. This relationship can be approximated by the following formula:

$$
D_{T}=F_{D}+M+S_{S}^{220}
$$

where

$$
\begin{aligned}
& D_{T}=\text { Ability to be Deterred, } \\
& F_{D}=\text { Fear of Death, } \\
& M=\text { Sense of Morality, and } \\
& S_{s}=\text { Susceptibility to Stigmatization. }
\end{aligned}
$$

To best curb the spread of HIV, the law should allocate liability according to each parties' relative susceptibility to deterrence. ${ }^{222}$ Because the impact of these factors increases with the knowledge of the potential for HIV infection, ${ }^{223}$ the ability to be deterred also increases with knowledge. ${ }^{24}$ Therefore, liability should be placed

${ }^{220}$ It is not suggested that these three factors are the only determinants of parties' susceptibility to deterrence. In fact, factors such as sexual drive, emotional needs, and machismo can also affect an individual's ability to be deterred. See GouLD, supra note 4, at 53-59 (describing various cultural barriers to guarding against HIV transmission); $i d$. at 78 (noting that "[f]or many young men [in Tanzania] the acronym AIDS stands for 'Acha Iniue Dogedego Siachi,' meaning in Swahili 'Let it kill me because I will never abandon the young ladies'"); PHILIPSON \& POSNER, supra note 4, at 218 (noting that safe sex causes a "loss of sexual enjoyment" for some individuals).

221 If a person is sufficiently close to death, he will likely be experiencing numerous symptoms that might lessen his sex drive. Thus, greater proximity to death would act as a factor deterring him from sexual activity. Similarly, as a person's proximity to death decreases, and if he is asymptomatic, health no longer becomes a prevailing factor in his decisions to have sex. He may, however, believe that he is "going to his maker" and thus must not perform certain acts that would lessen his opportunity for the pristine afterlife. Cf. GouLD, supra note 4, at 54 (noting that one survey indicates that over $50 \%$ of those individuals who die before they reach the age of 55 believe "in some sort of life after death"). Alternatively, he may repress any notions of death.

${ }_{222}$ This assertion assumes that, for those individuals who have not already been deterred by other factors, the closer they are to being deterred, the more likely that the increased deterrence gained by civil liability will cause them to avoid risky sexual behavior.

${ }^{223}$ The more aware an individual is that HIV might be transmitted in a contemplated sexual encounter, the more heavily these motivational factors will weigh on that person's thought process. A person who has no reason to suspect a risk of HIV transmission has little reason to consider death, morality, or stigma in deciding whether to engage in the sexual conduct. In contrast, a person concerned about the possibility of HIV transmission will weigh these factors in deciding whether to run the risks associated with the contemplated sexual conduct.

224 For example, a plaintiff who suspects that a defendant is HIV-infected will be 
on the individual with greater knowledge of the risk of HIV transmission. ${ }^{225}$ Table I provides an illustration of the manner in which the motivational factors vary with knowledge. ${ }^{226}$

TABLE I

MOTIVATIONAL ANALYSIS

\begin{tabular}{|c|c|c|}
\hline $\begin{array}{l}\text { KNOWLEDGE } \\
\text { LEVEL }\end{array}$ & MOTIVATION FACTORS & $\begin{array}{l}\text { ABILITY TO BE } \\
\text { DETERRED }\left[D_{\mathrm{T}}\right]\end{array}$ \\
\hline IGNORANCE & $\begin{array}{l}\text { Fear of Death: } X \\
\text { Morality: } Y \\
\text { Stigmatization: } Z\end{array}$ & $X+Y+Z$ \\
\hline SUSPICION & $\begin{array}{l}\text { Fear of Death: } X+X_{1} \\
\text { Morality: } Y+Y_{1} \\
\text { Stigmatization: } Z+Z_{1}\end{array}$ & $\begin{array}{l}\left(X+X_{l}\right)+ \\
\left(Y+Y_{l}\right)+ \\
\left(Z+Z_{l}\right)\end{array}$ \\
\hline $\begin{array}{c}\text { IMPUTED } \\
\text { AWARENESS }\end{array}$ & $\begin{array}{l}\text { Fear of Death: } X+X_{1}+X_{2} \\
\text { Morality: } Y+Y_{1}+Y_{2} \\
\text { Stigmatization: } Z+Z_{1}+Z_{2}\end{array}$ & $\begin{array}{l}\left(X+X_{1}+X_{2}\right)+ \\
\left(Y+Y_{1}+Y_{2}\right)+ \\
\left(Z+Z_{1}+Z_{2}\right)\end{array}$ \\
\hline AWARENESS & $\begin{array}{l}\text { Fear of Death: } X+X_{1}+X_{2}+X_{3} \\
\text { Morality: } Y+Y_{1}+Y_{2}+Y_{3} \\
\text { Stigmatization: } Z+Z_{1}+Z_{2}+Z_{3}\end{array}$ & $\begin{array}{l}\left(X+X_{1}+X_{2}+X_{3}\right)+ \\
\left(Y+Y_{1}+Y_{2}+Y_{3}\right)+ \\
\left(Z+Z_{1}+Z_{2}+Z_{3}\right)\end{array}$ \\
\hline
\end{tabular}

As seen in Table $\mathrm{I}$, the deterrence associated with the motivational factors increases incrementally with knowledge. In almost all situations, a defendant will possess the same degree or a greater degree of knowledge than the plaintiff. ${ }^{227}$ In those situations

motivated by the fear of death to a greater degree than if she is ignorant of the defendant's condition. Conversely, a defendant who is aware of his positive HIV status will be more influenced by a sense of morality to avoid transmitting the virus than if he merely suspects that he is infected.

${ }^{225}$ A more detailed analysis of the comparative knowledge theory is presented infra part IV.B.1. The purpose of the present discussion is to introduce the relationship between knowledge and the ability to be deterred.

${ }^{226}$ See supra text following note 81 (defining knowledge categories). Note that the subscripted variables indicate the differences in motivation between adjacent knowledge levels.

${ }^{227}$ Generally, HIV status is learned from test results or is inferred from conduct. Therefore, it is unlikely that a plaintiff will have greater knowledge as to the defendant's condition than the defendant. In fact, unless a defendant discloses his risk factors and/or HIV status to the plaintiff, his knowledge will generally be greater 
where the defendant has a greater degree of knowledge of his HIV status, he is more easily deterred. The following example illustrates this fact: Assume plaintiff is ignorant of defendant's condition $\left(D_{T}\right.$ $=X+Y+Z)$ and defendant suspects he is HIV-positive $\left(D_{T}=\left(X+X_{1}\right)\right.$ $\left.+\left(Y+Y_{1}\right)+\left(Z+Z_{1}\right)\right)$. The defendant's ability to be deterred will exceed plaintiff's by:

Relative $D_{T}=\left(\left(X+X_{1}\right)+\left(Y+Y_{1}\right)+\left(Z+Z_{1}\right)\right)-(X+Y+Z)$, or

Relative $D_{T}=X_{1}+Y_{1}+Z_{1}$.

Therefore, when the defendant's knowledge exceeds the plaintiff's, liability should be placed on the defendant. In the situation when the plaintiff's and the defendant's knowledge levels are equivalent, however, their relative susceptibilities to deterrence will be zero, indicating that further analysis is necessary to isolate the more deterrable party. ${ }^{228}$

Table II summarizes the possible knowledge combinations and resulting liability allocations. ${ }^{229}$ The table also illustrates the fact that the defendant will not be liable if he does not suspect, or have reason to suspect, that he might be HIV-positive. ${ }^{230}$

TABLE II

LIABILITY ALLOCATIONS FOR RESPECTIVE

LEVELS OF KNOWLEDGE

\begin{tabular}{c||c|c|c|c||}
\multicolumn{4}{c|}{ PLAINTIFF's KNOWLEDGE } \\
\cline { 2 - 6 } \multicolumn{1}{c|}{$\begin{array}{c}\text { DEFENDANT'S } \\
\text { KNOWLEDGE }\end{array}$} & Ignorance & Suspicion & $\begin{array}{c}\text { Imputed } \\
\text { Awareness }\end{array}$ & Awareness \\
\hline \begin{tabular}{|c|c|c|c||} 
Ignorance \\
Suspicion
\end{tabular} & $\begin{array}{c}\text { No cause } \\
\text { of action }\end{array}$ & $\begin{array}{c}\text { No cause } \\
\text { of action }\end{array}$ & $\begin{array}{c}\text { No cause } \\
\text { of action }\end{array}$ & $\begin{array}{c}\text { No cause } \\
\text { of action }\end{array}$ \\
\hline $\begin{array}{c}\text { Imputed } \\
\text { Awareness }\end{array}$ & Defendant & Plaintiff & Plaintiff & Plaintiff \\
\hline Defendant & Defendant & Plaintiff & Plaintiff \\
\hline Awareness & Defendant & Defendant & Defendant & Plaintiff \\
\hline
\end{tabular}

than the plaintiff's.

${ }^{228}$ See infra part IV.B.1.d for further analysis of the equivalent-knowledge scenario.

${ }^{229}$ Table II presupposes the conclusion reached infra part IV.B.1.d: Assumption of risk should be a viable defense when knowledge levels are equivalent.

${ }^{230}$ See supra part II.B.1.a (noting that if the defendant has no reason to know of his positive HIV status, he does not breach a duty to the plaintiff by engaging in sexual activity with her). 


\section{B. Benefits of a Comparative Knowledge Standard}

\section{Comparative Knowledge Effects Maximum Levels of Deterrence}

One result of the application of the comparative knowledge prong is that it will reduce the sexual transmission of HIV by maximizing the deterrence for all individuals engaging in risky behavior, not just for those infected with HIV. ${ }^{231}$ In fact, the allocations presented in Table II will help reduce the spread of HIV for two reasons. First, the liability rules will provide the defendant with an additional incentive to disclose his HIV status, because if he discloses this information he may protect himself from civil liability. Disclosure is beneficial to society because it promotes informed decision-making. Because the defendant already has the requisite knowledge to avoid transmission, disclosure to the plaintiff will encourage additional scrutiny in her decision-making process. It is hoped that informed decisions regarding risky sexual behavior will lead to protective measures that will reduce the spread of HIV. At a minimum, it will ensure that both parties have the information necessary to evaluate the consequences of their actions, thus increasing the chance that at least one of the parties will either insist on the use of a condom or will avoid the sexual encounter altogether.

Second, the allocations place the burden on the plaintiff when she has knowledge equivalent to or greater than the defendant because, in general, plaintiffs will be more deterred than similarly informed defendants. Knowledge of a potential partner's HIV status will have a more profound impact on a plaintiff's decision than the threat of tort liability will have on a defendant's decision, because the plaintiff faces the possibility of death, whereas the threat to the defendant is only monetary. ${ }^{232}$ Because it is to

${ }^{231}$ Unlike victims of torts in which the plaintiff is not causally related to the harm, potential HIV-infected plaintiffs may choose to modify their behavior to prevent the spread of HIV. First, plaintiffs can abstain from intimate sexual contact. Second, they can inquire into their partner's HIV status before engaging in high-risk activity. Third, plaintiffs can use condoms and spermicide to help reduce the chance of transmission. Fourth, and least effective, they can ensure that their sexual partners are not members of high-risk groups such as intravenous drug users, males who have engaged in homosexual activity, or people who have had many sexual partners. By modifying behavior through one or more of these strategies, potential plaintiffs can effectively contribute to a decline in the transmission of HIV.

232 The plaintiff's ability to be deterred may also be greater because she can 
society's advantage to promote a defendant's disclosure of his HIV status, a plaintiff should pay her own costs when she has equal or greater knowledge of the defendant's condition.

The following examination applies the preceding analysis to several knowledge scenarios. This examination will verify that the liability allocations presented in Table II will help reduce the spread of HIV by deterring individuals from engaging in risky sexual behavior. For clarity, plaintiffs and defendants will be grouped into the following categories based on their respective knowledge levels. In the first two categories the parties' knowledge is asymmetrical:

Plaintiff Ignorant; Defendant Suspicious or Aware (PI/DSA):

The plaintiff is unaware of the defendant's HIV status, and the defendant has reason to believe, or knows, that he is infected with HIV.

Plaintiff Suspicious; Defendant Aware (PS/DA):

The plaintiff has reason to believe that the defendant is infected with HIV, but defendant is certain that he is seropositive.

In the last two categories the parties have symmetrical knowledge:

\section{Symmetrical Ignorance (SI):}

Both parties are unaware of their own and their partner's HIV status and have no reason to believe that either is infected with HIV.

Symmetrical Suspicion/Awareness (SSA):

Each party has reason to believe or knows that the defendant is infected with HIV.

Each of these scenarios will be addressed in turn.

\section{a. Plaintiff Ignorant, Defendant Suspicious or Aware}

In the PI/DSA hypothetical, the plaintiff's and the defendant's knowledge levels are asymmetrical. The plaintiff is ignorant of the defendant's HIV status, whereas the defendant has reason to believe, or knows, that he is HIV-positive. In either scenario, the defendant, whose knowledge is greater, is more likely to be motivated by liability allocations than the plaintiff. Although his final decision may be influenced by thoughts of death and pangs of desire, the defendant will be better situated to consider the effects of liability than will a plaintiff who lacks his insight and may not weigh these competing concerns.

choose to have sex with uninfected persons. 
Shifting plaintiff's costs to the defendant in the PI/DSA scenario will also further the effort to decrease the spread of HIV, because it will encourage defendants to disclose their suspicions or actual knowledge about their HIV status to plaintiffs. In sum, in order to promote the deterrence of acts that lead to the spread of HIV, courts should find that plaintiffs in scenarios resembling the PI/ DSA case do not assume the risk of transmission.

\section{b. Plaintiff Suspicious, Defendant Aware}

In the PS/DA category, the plaintiff has reason to believe that the defendant is HIV-positive, but the defendant is certain that he carries the virus. This category has some of the same characteristics of the PI/DSA category. As with the previous scenario, the issue turns on which party will be more deterred by civil liability. Again, the defendant's knowledge gives him greater insight. Although this is a closer case, putting the liability on the defendant will help to decrease the spread of HIV, because it will encourage defendants to ensure that plaintiffs are fully informed of their sexual partners' HIV status.

\section{c. Symmetrical Ignorance}

In this instance, the defendant has no knowledge that he poses a risk to the plaintiff. Thus, the defendant's actions cannot be considered negligent, because he has not breached a duty to act as a reasonably prudent person would have acted under the circumstances. When the defendant is ignorant of any risk of HIV transmission, a prima facie case of negligence is not established, and, consequently, the assumption of risk defense is irrelevant. ${ }^{233}$

\section{d. Symmetrical Suspicion/Awareness}

The SSA scenario involves parties with equivalent levels of knowledge as to the defendant's HIV status. Either both parties have reason to believe that the defendant is infected with HIV, or both parties know that the defendant is infected. In both cases, the defendant will probably be considered prima facie negligent for the transmission of HIV. Moreover, motivational factors which correlate with knowledge ${ }^{234}$ are no longer useful to identify which

${ }^{233}$ See supra text following note 89 (noting that a defendant who is justifiably unaware of his HIV status will not be considered negligent).

${ }^{234}$ See supra notes $217-23$ and accompanying text (identifying the primary 
party is more easily deterred. Thus, other considerations must be explored to determine which party should bear the liability.

When the parties' relative levels of knowledge as to the defendant's HIV status are equivalent, the plaintiff should bear her own costs for several reasons. First, such a liability rule rewards the defendant for disclosing his HIV status. ${ }^{235}$ Second, if the burden were to remain on the defendant in the equivalent-knowledge scenario, then the defendant would always bear the monetary burden of disease transmission, ${ }^{236}$ and there would be no additional incentive for plaintiffs to avoid risky sexual behavior. Thus, allowing the assumption of risk defense in the equivalent-knowledge case will ensure that both parties have some increased deterrence from engaging in risky sexual acts. Lastly, the plaintiff should bear the burden when all else is equal because, as previously acknowledged, plaintiffs should be more easily deterred than defendants with equivalent knowledge. ${ }^{237}$

In sum, the analysis of the parties as grouped into the four categories described above supports the position that the compara-

motivational factors as fear of death, conformance with morality, and susceptibility to stigmatization).

${ }^{235}$ If the defendant discloses his HIV status he can escape prospective civil liability. See infra part IV.B.I (analyzing the benefits of disclosure).

${ }^{236}$ This is assuming that the plaintiff will never have greater knowledge as to the defendant's HIV status than does the defendant.

${ }^{237}$ See infra part IV.B.1 (analyzing plaintiffs' and defendants' relative susceptibilities to deterrence).

Some may argue that disparate treatment of plaintiffs and defendants can be rationalized by examining the ordinary factors that lead individuals to engage in sex. Physiology dictates that these drives will vary along gender lines. Men and women differ "most importantly in the libido department." WRIGHT, supra note 199, at 30. Whereas men, as a group, are eager and nondiscriminating, women are arguably passive and selective in their sexual encounters. See id. at 40 (stating that "natural selection encourages 'an undiscriminating eagerness in ... males and a discriminating passivity in ... females"); id. at 43 ("In one experiment, three fourths of the men approached by an unknown woman on a college campus agreed to have sex with her, whereas none of the women approached by an unknown man were willing."). The dichotomy that may exist between men and women may affect each group's ability to be deterred from sexual acts. Because plaintiffs of heterosexual orientation are more likely to be women, and defendants are more likely to be men, one could argue that it should also affect liability allocations. See HOMBS, supra note 38, at 10 (stating that "women are the fastest growing category of cases" of HIV infection); Brett-Smith \& Friedland, supra note 3, at 20 ("Women account for . . 61 percent of all cases [of HIV transmission] attributed to heterosexual contact."). Thus, even though this argument is not advanced in this Comment, it lends support to the conclusion that the viability of assumption of risk in the SSA scenario will lead to a reduction in the spread of HIV. 
tive knowledge standard will aid in deterring behavior that may result in the spread of HIV. When the plaintiff's knowledge is equivalent to that of the defendant (SSA), assumption of risk should be a viable defense because it will encourage other potential defendants to disclose their HIV status, thus aiding in the effort to deter plaintiffs from engaging in risky sexual behavior. When the plaintiff's knowledge of the defendant's HIV status is less than that of the defendant's (PI/DSA and PS/DA), assumption of risk should not apply for two reasons: first, because the defendant will give more weight to the consequences of civil liability, and second, because such a rule will encourage the defendant to disclose his HIV status.

2. A Clear and Consistent Rule: Comparative Knowledge as a General Solution to the Misinterpretation and Misunderstanding of the Assumption of Risk Doctrine

As previously stated, there are two main reasons why the courts do not consistently apply the assumption of risk defense: (1) too many of its terms are open for interpretation, and (2) its literal application leads to unjust results. ${ }^{238}$ The use of a comparative knowledge standard solves both of these problems by providing a bright-line test. Such a test would result in consistent rulings in the HIV-transmission context and in other substantive legal areas. Two examples help to prove this point.

First, consider the situation in Calahan v. Wood. ${ }^{239}$ In that case, even though the traditional elements of assumption of risk were satisfied, the court did not allow the defendant to escape liability. The outcome of the case contributes to the inconsistency surrounding the assumption of risk doctrine, while furthering legitimate societal goals. The same result, however, could have been reached if the court had simply compared the plaintiff's and the defendant's knowledge. At the point preceding the accident, the defendant's knowledge about the impending disaster was greater than that of the passenger plaintiff. ${ }^{240}$ This disparity in knowledge

${ }^{238}$ See supra part III.B.

${ }^{239} 465$ P.2d 169 (Utah 1970), overruled on other grounds by Randle v. Allen, 862 P.2d 1329 (Utah 1993). See supra notes 206-08 and accompanying text. This hypothetical "has baffled a great many law students, some judges, and unhappily a few very learned legal writers." KEETON ET AL., supra note 30, \& 68, at 485.

${ }^{240}$ The defendant was inevitably better informed as to whether he would be able 
would justify a denial of the defendant's assumption of risk defense because he was the party with greater knowledge. ${ }^{241}$

The preceding scenario illustrates that courts will not, under a comparative knowledge formulation of assumption of risk, be forced to apply incorrectly the assumption of risk defense to reach just results. Another advantage of comparative knowledge is that it decreases the need for extensive interpretation of the assumption of risk prongs by the courts. The standard of knowledge, the voluntary nature of the action, and the harms within the risk can all be interpreted very liberally by the court. Consequently, the courts will need to make fewer judgments as to whether each of these prongs is satisfied. Application of the defense will, instead, turn on a comparison of the parties' knowledge.

The benefits of this approach are also illustrated in the following hypothetical: An automobile accident occurs on New Year's Eve involving a drunk driver and a sober driver in which the drunk driver was driving negligently. Although a person driving on New Year's Eve voluntarily assumes a known risk that there will be drunk drivers on the road, courts refuse to relieve the drunk driver of liability. To reach this decision, a court must stretch the harmwithin-the-risk prong of the traditional assumption of risk defense. Under a comparative knowledge analysis, this confusing inquiry would be unnecessary. A court would interpret the harm-within-therisk prong very liberally so that all such harms are within the risk assumed. Then a court would look to the knowledge of the parties to determine whether the defense should be applied. In this case, although the plaintiff knew that there was a chance that drunk drivers would be on the road, the defendant knew for a certainty that he was drunk. ${ }^{242}$ A comparative knowledge analysis would

to swerve and miss the car, and he was undoubtedly in a better position to judge his prospective response time.

${ }^{241}$ Some cases have come close to comparing defendant's and plaintiff's knowledge in the context of assumption of risk. See, e.g., Higgins v. Mason, 174 N.E. 77, $79-80$ (N.Y. 1930) (finding that a passenger assumed the risk of a dangerous automotive condition of which the driver was unaware); see also McConville v. State Farm Mut. Auto. Ins. Co., 113 N.W.2d 14, 16 (Wis. 1962) (suggesting that a passenger may assume a certain risk by riding with a driver whose lack of skill or known habits present a hazard).

${ }^{242}$ In contrast, if the plaintiff knows that the defendant was driving drunk around a racetrack and, despite this fact, decides to take her car out onto the track, the plaintiff voluntarily assumes the known risk with the equivalent level of knowledge as the defendant. Thus, as intuition would dictate, the plaintiff assumes the risk and is barred from recovery. 
place liability on the defendant-the same result that is reached by contorting the present formulation of the assumption of risk doctrine but without the confusion.

\section{Law and Policy Support the Adoption of Comparative Knowledge}

Adoption of a comparative knowledge standard not only furthers societal goals by providing a means for reducing the spread of HIV, it is also supported by long-established principles of law and policy. This section first illustrates how basic theories of contract law support a comparative knowledge standard. Then, it discusses policy considerations, such as the last clear chance doctrine, that further bolster the application of the comparative knowledge standard.

\section{Comparative Knowledge and Contract Law Principles}

\section{a. Unconscionability}

Under basic unconscionability theory, courts are reluctant to uphold contracts in which one party takes advantage of his superior knowledge to the detriment of the other party. ${ }^{243}$ In such a case, the court will declare the contract unconscionable, finding "an absence of meaningful choice on the part of one of the parties [and] contract terms which [are] unreasonably favorable to the other party." 244 Because unconscionability has had such widespread

This point has been made by Keeton: "[O]ne who utilizes the services of a defendant engaged in an abnormally dangerous activity will be regarded as assuming the risk that is universally known to exist." KEETON ET AL., supra note $30, \S 79$, at 566; see also id. (stating that "a passenger in an airline will assume the risk that is normally associated with air travel even though the use of airplanes may be regarded as abnormally dangerous," and noting that an employee who "agrees to work with dangerous animals . . . assumes the risk, and cannot recover when they injure him"). In such cases, the defendant's and plaintiff's levels of knowledge are equivalent.

${ }^{243}$ See TEX. BUS. \& COM. CODE ANN. \$ 17.45(5) (West 1987) (stating that an unconscionable action is one in which an individual "takes advantage of the lack of knowledge" of another); Langemeier v. National Oats Co., 775 F.2d 975, 977-78 (8th Cir. 1985) (holding a contract unconscionable because the defendant had failed to provide the plaintiff with certain information); Bernard G. Helldorfer, Contracts and Commercial Litigation, 42 BUS. LAW. 614, 615 (1987) (stating that "it has long been recognized that sometimes one party may lack sufficient information . . . to bargain on equal terms, and courts in such instances may strike down or rewrite an agreement on the ground that it is unconscionable ${ }^{n}$ ).

241 Williams v. Walker-Thomas Furniture Co., 350 F.2d 445, 449 (D.C. Cir. 1965); E. ALLAN FARNSWORTH, CONTRACTS $\S 4.28$, at 314 (1982) (noting that courts still focus on the Williams court's definition of unconscionability); see also Shell Oil Co. $v$. 
application in the area of contract law, ${ }^{245}$ there is reason to conclude that it should also be advanced in the area of tort law. ${ }^{246}$

By holding that a plaintiff has assumed the risk of an accident, even when the plaintiff has not entered into an explicit exculpatory contract, the courts are essentially holding the plaintiff to an implied or fictional contract. ${ }^{247}$ If such a contract is based upon widely disparate knowledge, unconscionability principles should apply. ${ }^{248}$ It seems unconscionable that a defendant would be able to escape liability for transferring HIV to the plaintiff when the agreement to participate in sexual activity was unreasonably

Marinello, 307 A.2d 598, 602 (N.J. 1973) (finding unconscionability in a contract in which "the provisions ... [were] the result of [the franchisor's] disproportionate bargaining position and [were] grossly unfair"), cert. denied, 415 U.S. 920 (1974).

245 The concept of unconscionability is so well ingrained in contract law that courts will void existing contracts when there is a large disparity in the parties' bargaining positions. In fact, the UCC addresses "unconscionable" contracts and clauses, stating:

If the court as a matter of law finds the contract or any clause of the contract to have been unconscionable at the time it was made the court may refuse to enforce the contract, or it may enforce the remainder of the contract without the unconscionable clause, or it may so limit the application of any unconscionable clause as to avoid any unconscionable result.

U.C.C. $\$ 2-302(1)$ (1994). Although Article 2 of the UCC only applies to contracts for the sale of goods, courts can apply the UCC concept to other types of contracts by analogy or apply the analogous unconscionability provision in the Restatement (Second) of Contracts. See Restatement (SECOND) OF CoNTRACTS § 208 (1992).

${ }^{216}$ See Joseph P. Tomain, Contract Compensation in Nonmarket Transactions, $46 \mathrm{U}$. PrTT. L. REV. 867, 891 (1985) (noting that "[t]he distinction between torts and contracts ... is artificial"); $i d$. at $888-89$ (noting that because the rules and policy arguments in torts and contracts overlap, "[a] class of cases exists which, like ghosts, wanders the nether world between torts and contracts"); see also Martha C. Nussbaum, Skepticism About Practical Reason in Literature and the Law, 107 HARV. L. REV. 714, 732 (1994) (stating that similar ideas, "whether under the influence of economists, under that of the more radical thinkers, or even under the influence of the closely-related positions of Holmes," penetrate both torts and contract law).

${ }^{247}$ See ARTHUR L. CORBIN, CORBIN ON CONTRACTS $\$ 19$, at 27 (1952) (noting that a contract implied in law, also referred to as a "quasi-contract," is a fictional contract imposing an obligation "created by the law for reasons of justice, without any expression of assent and sometimes even against a clear expression of dissent"); see also Schott v. Westinghouse Elec. Corp., 259 A.2d 443, 449 (Pa. 1969) (imposing liability even though it was against the intentions of the parties).

${ }^{248}$ The concept of basing tort liability on the difference between the plaintiff's and defendant's knowledge is not novel. The court in Yaniger v. Calvert Bldg. \& Constr. Co., 37 A.2d 263 (Md. 1944), held that with respect to injuries sustained by a plaintiff entering the defendant's premises, "[ $[$ ] he true ground of liability is the proprietor's superior knowledge of the perilous instrumentality or the danger therefrom to persons going upon the property. It is when the perilous instrumentality is known to the owner or occupant, and not known to the person injured, that a recovery is permitted." Id. at 264. 
favorable to defendant. The defendant could have easily ensured that the plaintiff had this knowledge without unduly burdening himself.

Application of the comparative knowledge standard to the assumption of risk defense circumvents this unconscionability problem and ensures fairness in the defense's application. Plaintiffs will not be held to implied, exculpatory contracts when defendants' superior knowledge precludes plaintiffs from making truly informed decisions. In addition, comparative knowledge promotes the policy considerations underlying the unconscionability doctrine-it creates an incentive for defendants to engage in fair bargaining with plaintiffs.

\section{b. Misrepresentation}

Contracts between plaintiffs and defendants with differing levels of knowledge may also be voidable based on concepts of misrepresentation or concealment. As one commentator states:

The requirement of "assent," which is fundamental to the formation of a binding contract, implies in a general way that both parties to an exchange shall have a reasonably clear conception of what they are getting and what they are giving up. If the identity or the character of the property or service being bought or sold is overtly misrepresented by one of the contracting parties, then the other party's assent is obviously less than meaningful and any agreement that results will be regarded as voidable. ${ }^{249}$

Although some courts distinguish between cases in which the defendant makes an assertion and those in which he merely fails to reveal a particular fact, ${ }^{250}$ most courts hold that the latter constitutes misrepresentation when the discrepancy relates to a "basic assumption" and the failure to disclose "amounts to a failure to act in good faith." 251

${ }^{249}$ Marvin A. Chirelstein, Concepts and Case Analysis in the LAw OF CoNTRACTs 66 (1990); see also Mansfield, supra note 9, at 25-28 (comparing contract law and assumption of the risk).

${ }^{250}$ See CHIRELSTEIN, supra note 249, at 67 (raising the question of whether nondisclosure of a material fact should be treated as the legal equivalent of misrepresentation).

251 RESTATEMENT (SECOND) OF CONTRACTS, supra note 245, § 161(b). The "basic assumption" and "failure to act in good faith" requirements are intended to promote informed decision-making by a commercial buyer. Their primary application is to remove from the list of unconscionable contracts those "cases involving so-called market information which is typically the product of research and special expertise 
To further the policy goals supporting the misrepresentation defense, the assumption of risk defense should not be applied when the defendant has more knowledge than the plaintiff and the difference in knowledge goes to a basic assumption made by the plaintiff when deciding to engage in a particular activity. A comparative knowledge analysis curtails the use of the assumption of risk defense in this manner. In the context of HIV transmission, a defendant would not be able to invoke the defense if the plaintiff were unaware of a basic assumption (that is, that the defendant was HIV-positive) when the plaintiff decided to engage in sex with the defendant.

\section{Comparative Knowledge and Policy Considerations: The Last Clear Chance Doctrine}

Consideration of the difference between the plaintiff's and defendant's knowledge in an assumption of risk analysis is supported by the policies underlying the last clear chance doctrine. ${ }^{252}$ Once the defendant proves the plaintiff's contributory negligence, the plaintiff can regain her claim by establishing that the defendant had the last clear chance to avoid the accident. ${ }^{253}$ One premise behind the last clear chance doctrine is that it is economically efficient to reduce the total number of accidents. ${ }^{254}$ Society,

on the part of the potential buyer." CHIRELSTEIN, supra note 249, at 68 .

252 The last clear chance doctrine, which originated in England in 1842, see Kevin J. Grehan, Note, Comparative Negligence, 81 CoLUM. L. REV. 1668, 1678 \& n.57 (1981) (citing Davies v. Mann, 152 Eng. Rep. 588 (Ex. D. 1842)), is a rebuttal against the contributory negligence defense to negligent torts. See KEETON ET. AL., supra note 30, $\$ 65$, at 451 (discussing the contributory negligence defense to negligence actions).

${ }^{253}$ See KEETON ET AL., supra note $30, \S 66$ (noting that the claim of a plaintiff will be upheld, in a jurisdiction that applies a contributory negligence scheme, if the defendant had the last clear chance to avoid the harm); Robert N. Strassfeld, Causal Comparisons, 60 FORDHAM L. REv. 913, 930 (1992) (stating that "[t]he 'last clear chance' rule ... negates the bar to recovery that would result from the plaintiff's contributory negligence if the defendant had the last clear chance to avoid the harm").

${ }^{254}$ Another premise behind the last clear chance doctrine is that the individual who has the last opportunity to avoid the accident is more at fault. See Strassfeld, supra note 253, at $914 \mathrm{n} .8$ (noting that " [d] egrees of fault and proximity of causation are inextricably mixed" (citation omitted)). The rationale is that "if the plaintiff's negligence is complete when the injury occurs ... the defendant's actions then become the sole proximate cause of the injury." DeWolf \& Hander, supra note 204, at $163 \mathrm{n} .14$. This justification for the doctrine includes a notion of temporal order that has made last clear chance a "doctrinal muddle." Id. at 164; see also Strassfeld, supra note 253, at 930 (noting that the last clear chance doctrine "reflects an intuition about causal importance"). The temporal order aspect of last clear chance is largely 
therefore, does not want defendants to escape liability if they were better situated to avoid the accident. ${ }^{255}$ Unfortunately, no counterpart to the contributory negligence/last clear chance combination currently exists for the assumption of risk defense.

The inconsistency between the last clear chance and assumption of risk doctrines can be remedied if courts incorporate the difference between the defendant's and plaintiff's knowledge into the assumption of risk formula. For example, the plaintiff may know that the defendant is in a high-risk category for the transmission of HIV. If the defendant has this same knowledge, then the knowledge is symmetrical and the plaintiff will bear the cost of the HIV transmission. ${ }^{256}$ If, however, the defendant knows that he is HIV-positive, but the plaintiff is only aware that the defendant is in a high-risk group, the defendant should not be able to invoke the assumption of risk defense because he was in the better position to avoid transmission. Such findings will allow courts to achieve socially desirable results-liability will be placed on the person better able to avoid the accident; ${ }^{257}$ therefore, the incidence of HIV transmission should decrease.

\section{Comparative Knowledge: Necessary and Feasible}

\section{Why Present Tort Theories Are Not Sufficient to Deter the Spread of HIV}

The assumption of risk doctrine has come under attack in recent years:

The argument is that assumption of risk serves no purpose which is not fully taken care of by the other doctrines [lack of duty and contributory/comparative negligence]; that it adds only duplica-

irrelevant in the context of sexually transmitted diseases. It is not suggested, however, that last clear chance be applied literally; rather, the policies behind the doctrine can be promoted through application of comparative knowledge.

${ }^{255}$ This doctrine, however, would give defendants no incentive to avoid a harm that is partially caused by the plaintiff's negligence. See William Schofield, Davies v. Mann: Theory of Contributory Negligence, 3 HARv. L. REV. 263, 270-71 (1889) (discussing last clear chance in terms of the public policy of creating incentives for parties to exercise proper care).

${ }^{256}$ See supra Table II.

${ }^{257}$ The person with more knowledge is better able to determine whether the act in question will result in harm. 
tion adding to confusion; and that it results in denial of recovery in some cases where it should not be denied. ${ }^{238}$

This conclusion, however, is not accurate, especially in the context of AIDS. In fact, accepting such an argument may lessen the deterrent value of the negligence cause of action.

\section{a. Assumption of Risk as a Lack of Duty}

Some legal scholars argue that assumption of risk essentially negates any duty that the defendant owes the plaintiff. They assert that it would be simpler to say that because the plaintiff "consents," the defendant owes no duty to the plaintiff in the first place. Although both duty negation and assumption of risk act to relieve the defendant of liability, there are key procedural differences between the two theories. ${ }^{259}$

Allowing assumption of risk to collapse into the duty element of the prima facie case is "a disservice to the plaintiff, imposing upon [her] a real procedural disadvantage, with no corresponding gain. ${ }^{\text {260 }}$ The plaintiff would not only have to prove that the defendant owed her a particular duty, she also would have to demonstrate that she did not voluntarily consent to the defendant's actions. Not only is this heightened burden unnecessarily harsh on plaintiffs, but it is also particularly problematic in the context of AIDS. By creating a presumption that the plaintiff has assumed the risk of HIV transmission, the duty of a seropositive individual not to transfer the virus to others is greatly minimized. The minimal added deterrence that such a presumption ascribes to plaintiffs is substantially outweighed by the diminished deterrence ascribed to defendants. Thus, the no-duty permutation of assumption of risk will not bring about a reduction in HIV transmission.

${ }^{258}$ KEETON ET AL., supra note $30, \S 68$, at 493.

259 The assumption of risk doctrine only applies if the plaintiff has met the burden of proving that the defendant was negligent. Once the plaintiff has met that burden, the burden of proof shifts to the defendant, who must demonstrate that the plaintiff assumed the risk at issue. If assumption of risk is viewed as a lack of duty, however, the plaintiff must prove the elements of the prima facie case and must demonstrate that she did not consent to be exposed to the risk at issue.

${ }^{260}$ KEETON ET AL., supra note $30, \S 68$, at 494. 


\section{b. Assumption of Risk as a Form of Contributory/Comparative Negligence}

Critics also assert that the benefits derived from the assumption of risk defense are the same as those achievable through the application of contributory and comparative negligence-that assumption of risk is just another form of contributory or comparative negligence. ${ }^{261}$ The two defenses, however, are different in one very important respect:

[C]ontributory negligence involves inadvertence or unintentional failure to measure up to a proper standard of self-protection, while assumption of risk involves the conscious and deliberate decision to encounter a known risk.... [I]t is suggested [that] contributory negligence is measured by the objective standard of the reasonable [person] while assumption of risk is controlled by the subjective intent of the plaintiff [herself]. ${ }^{262}$

One court elaborated on this distinction, stating:

[A]ssumption of risk involves the meeting of a subjectively known risk, whereas contributory negligence may involve the plaintiff exposing [herself] to a danger of which [she] was subjectively unaware but which would have been apparent had [she] used due care. With the former, plaintiff's conduct may be quite reasonable because its advantages outweigh its risks; but regardless, if plaintiff is injured,.... [she] is barred from recovering because of [her] failure to exercise due care. ${ }^{263}$

The differences between the assumption of risk defense and contributory negligence are especially apparent when viewed in the context of HIV transmission. To assert the assumption of risk defense, the defendant must show that the plaintiff voluntarily agreed to engage in sexual relations with the defendant and had knowledge of the risks involved. With respect to contributory

${ }^{261}$ The courts have often confused assumption of risk with contributory negligence. One reason for this is that the two defenses both provide a bar to a plaintiff's recovery. See id. $\$ 68$, at 481 ("Since either [assumption of risk or contributory negligence] traditionally was sufficient to bar the action, it usually made no practical difference what the defense was called, and it is not surprising that the two have not been clearly distinguished, and are quite commonly confused.").

${ }^{262}$ Wade, supra note 161, at 11-12; see also Mansfield, supra note 9, at 53 (stating that contributory negligence "extends beyond the cases in which [a plaintiff] appreciated the risk and includes those in which he merely ought to have appreciated it").

${ }^{263}$ Smith v. Seven Springs Farm, Inc., 716 F.2d 1002, 1006 (3d Cir. 1983); see also KEETON ET AL., supra note $30, \S 68$, at 495 (stating that "assumption of risk is governed by the subjective standard of the plaintiff himself, whereas contributory negligence is measured by the objective standard of the reasonable man"). 
negligence, however, the defendant has the burden of proving that "the plaintiff had a duty to protect herself from diseases such as AIDS, ${ }^{264}$ that the plaintiff breached that duty, ${ }^{265}$ and that the breach was causally related, both directly and proximately, to real injuries sustained by the plaintiff. ${ }^{266}$ The defenses only overlap when "the plaintiff makes an unreasonable choice to incur [a] risk." ${ }^{267}$ Thus, assumption of risk covers a myriad of fact patterns that are untouched by the contributory and comparative negligence defenses-those fact patterns in which a plaintiff may assume the risk even though she acted as a reasonable person would have in the circumstances.

The fact that assumption of risk overlaps contributory and comparative negligence when a plaintiff's assumption is unreasonable is not a sufficient reason for abolishing the assumption of risk defense. By recognizing both the assumption of risk and contributory/comparative negligence defenses, ${ }^{268}$ a plaintiff's deterrence from engaging in risky behavior will be greater. The combined effect of the two types of defenses will be to increase the scope of factual scenarios in which a plaintiff will be unable to recover.

\section{Avoidance of Liability: The Doctrine of Willful Blindness}

The proposal advocated in this Comment focuses on subjective knowledge. ${ }^{269}$ Consequently, individuals could potentially avoid liability by "shut[ting] their eyes to what was plainly to be seen." 270

264 Zakarin, supra note 168, at 292.

${ }^{265}$ The plaintiff's duty may be breached if she (1) does not "insist[] that the defendant wear a condom," (2) does not refrain from engaging in sexual intercourse, or (3) does not seek proof of the defendant's HIV status. Id.

${ }_{266}$ See KEETON ET AL., supra note 30, § 65, at 453, 456-57 (discussing the elements of the contributory negligence defense). The analysis required to prove the plaintiff's assumption of risk is analogous to that required for the consent defense, whereas the analysis surrounding the plaintiff's contributory negligence more closely resembles the analysis used to prove the defendant's negligence. See id. $\S 18$, at 112-13 (discussing the consent defense to intentional torts); see also supra note 68 (listing the elements of the negligence cause of action).

${ }^{267}$ KEETON ET AL., supra note $30, \S 68$, at 482; see also Koshorek v. Pennsylvania R.R., 318 F.2d 364, 366-67 (3d Cir. 1963) (discussing a jury charge on comparative negligence that failed to distinguish it from assumption of risk).

${ }_{268}$ See KEETON ET AL., supra note $30, \S 68$, at 482 (noting that the assumption of risk defense and comparative/contributory negligence can coexist).

${ }^{269}$ Because subjective knowledge may be proved through circumstantial evidence or may be imputed through the use of the "imputed awareness" knowledge category, it is more accurately defined as a semi-subjective, semi-objective test.

${ }^{270}$ United States v. Benjamin, 328 F.2d 854, 863 (2d Cir. 1964). 
An individual who thinks that he might be seropositive might avoid testing for fear that a positive result would increase his potential for civil liability.

It is possible to mitigate this knowledge dilemma through the use of the "willful blindness" doctrine. ${ }^{271}$ In essence, "a defendant's knowledge of a fact may be inferred from willful blindness to the existence of the fact." ${ }^{272}$ Courts may substitute constructive knowledge for actual knowledge, finding that the defendant's knowledge was greater than that of a plaintiff with equivalent actual knowledge of the defendant's sexual history. In such cases, courts may hold that the defendant was aware of his HIV status because he had strong reason to know and could have found out through a simple test. The same courts would likely find that a plaintiff, with similar knowledge as to the defendant's HIV status, did not have the defendant's awareness because she was not in a position to find out with certainty and thus could not be held to be willfully blind. Therefore, a defendant's attempt at evading knowledge would not work to his benefit.

Even if courts make use of the willful blindness doctrine, however, it is possible that there will still be some decrease in the number of people who get tested. ${ }^{273}$ This decrease is minimized

271 The concept of willful blindness originated in English law. In the 1861 case of Regina $v$. Sleep, a judge ruled that the defendant could not be convicted of unlawfully possessing naval stores unless he "knew that the stores were marked, or . . . wilfully abstained from acquiring that knowledge." Regina v. Sleep, 169 Eng. Rep. 1296, 1302 (Cr. Cas. Res. 1861) (Willes, J.).

One of the leading cases on willful blindness is United States v. Jewell, 532 F.2d 697 (9th Cir.), cert. denied, 426 U.S. 951 (1976). In Jewell, a stranger approached the defendant, asking him whether he wanted to buy marijuana and/or drive the stranger's car across the border for $\$ 100$. The defendant declined to purchase the drugs, but he agreed to drive the car. It was later found that there were drugs in a secret compartment of the car. The defendant knew of the compartment's existence, but he was not aware that it contained drugs. The court convicted the defendant for knowingly possessing a controlled substance, stating that the defendant had "a conscious purpose to avoid learning the truth." Id. at 700. The court concluded that '[ $t$ ] act 'knowingly,' therefore, is not necessarily to act only with positive knowledge, but also to act with an awareness of the high probability of the existence of the fact in question." Id.

${ }^{272}$ United States v. Hiland, 909 F.2d 1114, $1129-30$ n.22 (8th Cir. 1990); see also United States v. St. Michael's Credit Union, 880 F.2d 579, 584 (1st Cir. 1989) ("A 'willful blindness [jury] instruction is appropriate when: (1) defendant claims a lack of knowledge, (2) the facts suggest a conscious course of deliberate ignorance, and (3) the instruction, taken as a whole, cannot be misunderstood by a juror as mandating such an inference." (quoting United States v. Hogan, 861 F.2d 312, 316-17 (1st Cir. 1988))).

${ }^{273}$ This deterrence is potentially problematic because society derives a number of 
in two respects. First, individuals can get tested anonymously. ${ }^{274}$ If an individual chooses to be tested in an anonymous capacity, no medical record will exist for use in discovery. ${ }^{275}$

Second, numerous compelling reasons for individuals to get tested still exist. A person may want to get tested in order to assure his partner that he is not infected with the virus. ${ }^{276}$ If the person is an altruist, he may want to get tested to ensure that he avoids infecting others. ${ }^{277}$ If the person is an egoist, he may want to find out his status so that, if he tests positive, he can avoid engaging in

benefits from the testing process. One commentator has summarized some of these benefits:

1. To identify seropositive individuals so that proper education and counseling can be effected to prevent further transmission of the virus.

2. To identify seropositive individuals so that proper medical care can be administered early in the course of the disease. Studies have shown that HIV-infected patients may benefit from chemotherapy and from chemoprophylaxis and immunizations against selective diseases before the onset of clinical AIDS.

3. To identify, evaluate and counsel sexual partners and needle-sharing partners of seropositive individuals.

4. To evaluate a patient with certain clinical signs and symptoms.

5. To enable a physician and patient to make certain therapeutic and management decisions.

TASK FORCE REPORT, supra note 10, at 21-22. Although there are many benefits to be reaped from testing, the benefits are limited. See GURRAN ET AL., supra note 47, at iv ("At this time, legally authorized screening programs would be unlikely to achieve any clear public health benefit[, s]ince there is currently no treatment or vaccine for prevention."). Although Curran's book was written prior to the discovery of AZT, his hypothesis is still valid, as there is no cure for AIDS.

274 See AIDS INST., NEW YORK STATE DEP'T OF HEALTH, HEALTH FORM No. 2566z, INFORMED CONSENT TO PERFORM AN HIV RELATED TEST 1 (1991) [hereinafter CONSENT FORM] (stating to potential test recipients: "If you do not want anyone to know your test results or that you were tested, you can go to an anonymous test site. You will not be asked your name or address.").

${ }^{275}$ See PHILIPSON \& POSNER, supra note 4, at 147 ("Unless records of test results are kept and made available to tort plaintiffs or to prosecutors, which because of concerns about privacy is unlikely, it would be difficult to prove that the carrier knew he was such because he had been tested and the result disclosed to him.").

${ }^{276}$ See id. at 86 (stating that a person may "decide to be tested in the hope that if he tested negative [his partner] would consent to have risky sex with him"); id. at 85 86 (recognizing that "a person who has either tested negative or knows himself to have a very low probability of being infected may be unwilling to have risky sex with another person unless the latter agrees to be tested and to reveal the result").

$277 \mathrm{See} i d$. at 105 (noting that "altruists [may be] concerned with the risk of infecting their sexual partners"); see also NATIONAL RESEARCH COUNCIL, supra note 34 , at 279 (addressing altruism and noting that "[s]tudies of diverse groups of gay men ... have shown that those who are seropositive take more precautions against spreading the virus than those who are seronegative (who presumably are protecting themselves)"). 
safe sex. ${ }^{278}$ Apart from the sex-related reasons for testing, persons may want to get tested for the following additional reasons:

A person may decide to be tested because it is a condition of obtaining life insurance or medical insurance or a job that he wants. Or because he wants to conduct his life with a realistic view to its likely duration. Or because he suspects that he is infected and believes that treatment with AZT, or other therapies, will be more effective the sooner treatment is begun .... Or because he wants to give (or sell) blood. A woman may want to be tested in order to know whether she is likely to bear children who are infected with HIV and doomed to die prematurely-or may want to learn whether she is doomed so that she can have children before it is too late. ${ }^{279}$

In sum, the combination of (1) the use of the willful blindness doctrine and (2) the remaining incentives which encourage testing will help to obviate any decrease in testing which may result from the implementation of a comparative knowledge analysis.

${ }^{278}$ See PHILIPSON \& POSNER, supra note 4, at 105 (stating that "egoists . . . want to know their infection status so that they can discontinue safe sex in the event that they are already infected and therefore have less to lose from engaging in risky sex than if they thought they were negative for the virus").

${ }^{279} I d$. at 106 (footnotes omitted). The New York State Department of Health informs potential testers of the following benefits to testing:

If you test negative:

[1] Your doctor or counselor will tell you how to protect yourself from getting infected with the virus in the future.

[2] You can end the fear which may come from not knowing if you are infected.

If you test positive:

[1] Your doctor can give you medical care and treatment that can help you stay healthy and can slow down HIV illness.

[2] Your doctor can tell you how to prevent passing the virus to others.

[3] If you have had a child since you were infected, your child may need additional care and treatment. Your doctor can provide information about medical care available for children who may be infected with HIV.

[4] If you are a pregnant woman, your doctor can provide the care you need and information about services and options available to you. Your doctor can tell you about the risks of passing HIV infection to your baby and the medical care available for babies who may be infected with HIV.

[5] If you are thinking of having a child, you will be told about the possibility of passing the virus to your baby.

CONSENT FORM, supra note 274 , at 1. 


\section{CONCLUSION}

The far-reaching psychological and social consequences of a deadly infectious disease such as AIDS have not been experienced since polio and smallpox plagued our society. ${ }^{280}$ "This good fortune means that we lack recent social and political experience in dealing with such problems." ${ }^{281}$ As a result, HIV-transmission rates continue to rise. Until the medical community can curtail this rise by curing people or immunizing them from HIV, the legal system must play an important role in minimizing the effects of AIDS. Courts will be faced with many difficult decisions-decisions that will not only affect the parties involved, but will also have positive or negative societal consequences.

The proposal developed in this Comment-interpretation of the assumption of risk doctrine in terms of comparative knowledge-is intended to assist the court system in lessening the confusion surrounding the current assumption of risk doctrine and rendering verdicts that will create equitable rules to guide individual behavior. In the context of AIDS, such rules will further society's goal of decreasing the spread of HIV. By assigning liability allocations based on parties' relative levels of knowledge, the comparative knowledge test effects maximum levels of deterrence of engaging in high-risk sexual behavior. It not only deters defendants by holding them liable for transmitting the virus to nonconsenting plaintiffs, but also deters plaintiffs when they have the requisite knowledge to avoid the harm. The test creates bright-line rules to guide potential parties' behaviors and encourages defendants to disclose their HIV status, thus promoting informed decision-making. Employment of the comparative knowledge standard should reduce the number of sexual encounters that pose a risk of HIV transmission. Such a result will lessen the drain on society's resources and, more importantly, will reduce the number of individuals who will be affected by the AIDS crisis.

${ }^{280}$ See GouLd, supra note 4, at 1-2 (chronicling the spread of various diseases throughout the world); Osborn, supra note 10, at 17-18 (commenting on the polio epidemic of the mid-20th century).

${ }^{281}$ Brandt, supra note 129 , at 42. 
